\title{
Neurochemical and Neurotoxic Effects of MDMA (Ecstasy) and Caffeine After Chronic Combined Administration in Mice
}

\author{
Anna Maria Górska ${ }^{1}$ - Katarzyna Kamińska ${ }^{1}$ - Agnieszka Wawrzczak-Bargiela ${ }^{2}$. \\ Giulia Costa ${ }^{3}$ - Micaela Morelli ${ }^{3} \cdot$ Ryszard Przewłocki $^{2}$ - Grzegorz Kreiner ${ }^{4}$. \\ Krystyna Golembiowska ${ }^{1}$
}

Received: 4 August 2017 / Revised: 4 October 2017 / Accepted: 18 October 2017 /Published online: 13 November 2017

(C) The Author(s) 2017. This article is an open access publication

\begin{abstract}
MDMA (3,4-methylenedioxymethamphetamine) is a psychostimulant popular as a recreational drug because of its effect on mood and social interactions. MDMA acts at dopamine (DA) transporter (DAT) and serotonin (5-HT) transporter (SERT) and is known to induce damage of dopamine and serotonin neurons. MDMA is often ingested with caffeine. Caffeine as a non-selective adenosine A1/A2A receptor antagonist affects dopaminergic and serotonergic transmissions. The aim of the present study was to determine the changes in DA and 5-HT release in the mouse striatum induced by MDMA and caffeine after their chronic administration. To find out whether caffeine aggravates MDMA neurotoxicity, the content of DA and 5-HT, density of brain DAT and SERT, and oxidative damage of nuclear DNA were determined. Furthermore, the effect of caffeine on MDMA-induced changes in striatal dynorphin and enkephalin and on behavior was assessed. The DA and 5-HT release was determined with in vivo microdialysis, and the monoamine contents were measured by HPLC with electrochemical detection. DNA damage was assayed with the alkaline comet assay. DAT and SERT densities were determined by immunohistochemistry, while prodynorphin (PDYN) and proenkephalin were determined
\end{abstract}

Krystyna Gołembiowska nfgolemb@cyf-kr.edu.pl

1 Department of Pharmacology, Institute of Pharmacology, Polish Academy of Sciences, Smętna 12 Street, 31-343 Kraków, Poland

2 Department of Molecular Neuropharmacology, Institute of Pharmacology, Polish Academy of Sciences, Kraków, Poland

3 Department of Biomedical Sciences, Section of Neuropsychopharmacology, University of Cagliari, Cagliari, Italy

4 Department of Brain Biochemistry, Institute of Pharmacology, Polish Academy of Sciences, Kraków, Poland by quantitative PCR reactions. The behavioral changes were measured by the open-field (OF) test and novel object recognition (NOR) test. Caffeine potentiated MDMA-induced DA release while inhibiting 5-HT release in the mouse striatum. Caffeine also exacerbated the oxidative damage of nuclear DNA induced by MDMA but diminished DAT decrease in the striatum and worsened a decrease in SERT density produced by MDMA in the frontal cortex. Neither the striatal PDYN expression, increased by MDMA, nor exploratory and locomotor activities of mice, decreased by MDMA, were affected by caffeine. The exploration of novel object in the NOR test was diminished by MDMA and caffeine. Our data provide evidence that long-term caffeine administration has a powerful influence on functions of dopaminergic and serotonergic neurons in the mouse brain and on neurotoxic effects evoked by MDMA.

Keywords Dopamine $\cdot$ Serotonin $\cdot$ Microdialysis $\cdot$ Oxidative stress $\cdot$ Mice $\cdot$ MDMA $\cdot$ Caffeine

\section{Introduction}

MDMA (3,4-methylenedioxymethamphetamine) known as "ecstasy" is one of the most popular illicit drugs with empathogenic properties. MDMA acting at dopamine (DA) transporter (DAT) and serotonin (5-HT) transporter (SERT) stimulates non-exocytotic release of DA and 5-HT (Baumann et al. 2005; Sulzer et al. 2005). In rodents, MDMA has a preferential affinity for SERT over DAT, so it exerts a more pronounced effect on 5-HT release (Rudnick and Wall 1992). After entering the cell via intracellular transport or diffusion, MDMA alters vesicular monoamine transporter (VMAT-2) and causes an increase in cytoplasmic DA and 5-HT concentrations (Sulzer et al. 2005). This effect is intensified by inhibition of 
monoamine oxidase type B (MAO-B) located in the outer membrane of the mitochondria of serotonergic neurons (Leonardi and Azmitia 1994). MDMA has been shown to elicit long-lasting neurotoxic effects which vary depending on gender and strain of animals (Brodkin et al. 1993; Colado et al. 2001; Costa et al. 2013; McCann et al. 2005). MDMA and its metabolites are thought to contribute to reactive oxygen species (ROS) formation and to cause selective 5-HT neuron damage in rats (de la Torre and Farre 2004; Sprague and Nichols 2005). Similarly, the damage in serotonergic system was also observed in non-human primates and in the human brain (Green et al. 2003; Ricuarte et al. 1988).

Numerous complex mechanisms have been identified as contributors to the neurotoxic effects of MDMA. Oxidative stress and excitotoxicity represent important mechanisms causing neuronal damage by MDMA (Cadet et al. 2001). MDMA has also been shown to trigger neuroinflammation which seems to be linked with glial activation, in particular microglial activation (Costa et al. 2013, 2014; Frau et al. 2013; LopezRodriguez et al. 2014). Other putative mechanisms of MDMA neurotoxicity include hyperthermia, metabolic toxic products, and apoptosis (Capela et al. 2007; Green et al. 2004).

Toxic and inflammatory effects of MDMA are exacerbated by its co-administration with other psychoactive substances (Khairnar et al. 2010, 2014). Caffeine is commonly consumed with MDMA in energy drinks to reduce drowsiness and fatigue, or it is present in illicit drug preparations, e.g., in ecstasy pills (Peacock et al. 2017). Molecular mechanism of caffeine action in the brain is based on adenosine receptor antagonism. The targets of caffeine actions include G-protein-coupled adenosine $\mathrm{A} 1$ and $\mathrm{A} 2 \mathrm{~A}$ receptors. In a microdialysis study, perfusion with caffeine caused an increase in DA release which was mimicked by the selective A1 receptor antagonist DPCPX, while $\mathrm{A} 1$ receptor agonists, but not adenosine A2A agonists, depressed DA levels (Okada et al. 1997). It is also suggested that adenosine $\mathrm{A} 1$ receptors present on glutamatergic neurons may be involved in striatal DA release (Borycz et al. 2007).

Caffeine in high doses elevates messenger RNA (mRNA) coding for opioid neuropeptides deriving from prodynorphin (PDYN) and proenkephalin (PENK) (Svenningsson et al. 1997). Medium-sized spiny GABA neurons projecting to the substantia nigra express D1 receptor as well as neuropeptides derived from PDYN (Vincent et al. 1982). On the other hand, medium-sized spiny neurons projecting to the globus pallidus express D2 receptor (Gerfen et al. 1990) as well as PENKderived peptides (Curan and Watson 1995). DA release increased by amphetamines activates neurons that express D1 receptors and PDYN, but not those that express D2 receptors and PENK (Granado et al. 2014; Johansson et al. 1994). By contrast, caffeine increases the activity of both types of neurons (Johansson et al. 1994).

Caffeine augmented many effects associated with MDMA use. The hyperthermia produced by MDMA in rats was exacerbated by caffeine (McNamara et al. 2006; VanattouSaiffoudine et al. 2010a, b). MDMA-induced hyperthermia and tachycardia but not hyperlocomotion were promoted by caffeine in rats. The activation of $\mathrm{D} 1$ receptors and A2A receptors and phosphodiesterase (PDE) inhibition were proposed as mechanisms of these synergistic interactions (Vanattou-Saïfoudine et al. 2010a, b, 2012). Other studies showed that administration of caffeine prior to MDMA in mice potentiated the increase in locomotor activity induced by MDMA (Camarasa et al. 2006) and enhanced MDMAinduced DA release in rat striatal slices via blockade of A1 receptors (Vanattou-Saïfoudine et al. 2011). Our earlier results indicated that exacerbation of MDMA effect on DA and 5-HT release by caffeine in mice was mediated via adenosine $\mathrm{A} 1$ and A2A receptors (Górska and Gołembiowska 2015). The results of Khairnar et al. (2010) and Frau et al. (2016) demonstrated that neuroinflammatory response induced by MDMA in adult $\mathrm{C} 57 \mathrm{BL} / 6 \mathrm{~J}$ mice and mice treated in adolescence with MDMA was potentiated by caffeine. The abovementioned data suggest that caffeine increases MDMA-related neurotoxicity. On the other hand, the results of Ruiz-Medina et al. (2013) showed that 22-day pretreatment with a low dose of caffeine completely prevented MDMA-induced neuroinflammation in CD1 mice. This raises the question about a longterm caffeine effect on MDMA neurotoxicity.

The aim of the current investigation was to determine changes in DA and 5-HT release in the mouse striatum induced by MDMA and caffeine. Both drugs were administrated repeatedly in a way mimicking recreational use by young people in dance clubs. To find out whether caffeine facilitates MDMA neurotoxicity, the content of DA and 5-HT, the density of brain DA and 5-HT transporters as markers of nerve terminal damage, and the oxidative damage of nuclear DNA were determined. Since D1 receptors present in medium-sized spiny GABA neurons projecting to the substantia nigra seem to play a role in MDMA neurotoxicity, the effect of caffeine on MDMA-induced changes in PDYN and PENK gene expressions was also examined. In addition, because caffeine could affect behavioral responses, we assessed the effect of chronic caffeine administration on some behavioral parameters associated with MDMA administration.

\section{Materials and Methods}

\section{Animals}

Experiments were performed on adult male ( $8-10$ weeks old) C57BL/6J inbred mice. The animals were housed 5-7 per cage, under a 12-h light/12-h dark cycle, with free access to standard food and tap water. The experiments were conducted in accordance with the European Union guidelines regarding the care and use of laboratory animals (Council Directive 86/ 
609/EEC of November 24, 1986) and were approved by the II Local Bioethics Commission (Kraków, Poland).

\section{Drugs and Reagents}

Caffeine (CAF), was obtained from Sigma-Aldrich (Poznań, Poland) while MDMA was purchased from Toronto Research Chemicals Inc. (Canada). Ketamine hydrochloride and xylazine hydrochloride were supplied by Biowet (Puławy, Poland). Caffeine and MDMA were dissolved in $0.9 \% \mathrm{NaCl}$. All injections were done via intraperitoneal (ip) route, and control animals received their respective vehicles. The chemicals used for high-performance liquid chromatography (HPLC) were purchased from Merck (Warsaw, Poland).

\section{Pattern of Drug Administration}

Mice received repeated doses of MDMA $(4 \times 10 \mathrm{mg} / \mathrm{kg}$ every $2 \mathrm{~h}$ ) for 2 days ip and CAF $(2 \times 5 \mathrm{mg} / \mathrm{kg}$ every $4 \mathrm{~h})$ for 2 days ip. After 5 days free of MDMA treatment, the animals received the next series of "binge" injections. Between binge injections, animals received caffeine $(2 \times 5 \mathrm{mg} / \mathrm{kg})$ or saline for 5 days. This cycle of treatments was repeated 3 times as shown on the diagram below.

\section{Brain Microdialysis}

Animals were anesthetized with ketamine $(7.5 \mathrm{mg} / \mathrm{kg})$ and xylazine $(1 \mathrm{mg} / \mathrm{kg})$, and vertical microdialysis probes were implanted into the striatum using the following coordinates: AP + 1.0, L + 1.8, and V - 3.8 (Paxinos and Franklin 2008). On the next day, probe inlets were connected to a syringe pump (BAS, IN, USA) which delivered an aCSF composed of $(\mathrm{mM}) \mathrm{NaCl} 147, \mathrm{KCl} 2.7, \mathrm{MgCl}_{2} 1.0$, and $\mathrm{CaCl}_{2} 1.2$, at $\mathrm{pH} 7.4$ at a flow rate of $1.5 \mu \mathrm{l} / \mathrm{min}$. After $1 \mathrm{~h}$ of the washout period, three basal dialysate samples were collected every $30 \mathrm{~min}$; then, animals were injected with a challenging dose of an appropriate drug as indicated in the figure captions and fraction collection continued for $360 \mathrm{~min}$. At the end of the experiment, the mice were sacrificed and their brains were histologically examined to validate the probe placement.

\section{Analytical Procedure}

DA and 5-HT contents in dialysate fractions were analyzed by HPLC with coulochemical detection. Chromatography was performed using an Ultimate 3000 System (Dionex, USA), coulochemical detector Coulochem III (model 5300, ESA, USA) with 5020 guard cells, 5014B microdialysis cell, and Hypersil Gold-C18 analytical column $(3 \times 100 \mathrm{~mm})$. The mobile phase was composed of $0.1 \mathrm{M}$ potassium phosphate buffer adjusted to $\mathrm{pH}$ 3.6, $0.5 \mathrm{mM}$ EDTA, $16 \mathrm{mg} / 1$ 1-octanesulfonic acid sodium salt, and $2 \%$ methanol. The flow rate during analysis was set at $0.7 \mathrm{ml} / \mathrm{min}$. The applied potential of a guard cell was $+600 \mathrm{mV}$, while those of microdialysis cells were $E_{1}=-50 \mathrm{mV}$ and $E_{2}=+300 \mathrm{mV}$ with a sensitivity set at $50 \mathrm{nA} / \mathrm{V}$. The chromatographic data were processed by Chromeleon v. 6.80 (Dionex, USA) software, run on a personal computer.

\section{The Tissue Content of DA, 5-HT, and Their Metabolites}

Animals were sacrificed by decapitation $3 \mathrm{~h}$ after cessation of treatment with drugs. Brains were separated, and several brain regions (striatum, frontal cortex) were dissected in anatomical borders. The tissue levels of DA, 5-HT, 3,4dihydroxyphenylacetic acid (DOPAC), homovanillic acid (HVA), and 5-hydroxyindoleacetic acid (5-HIAA) were measured using a HPLC with electrochemical detection. Briefly, tissue samples of brain structures were homogenized in icecold $0.1 \mathrm{M} \mathrm{HClO}_{4}$ and were centrifuged at $10000 \times \mathrm{g}$ for 10 min at $4{ }^{\circ} \mathrm{C}$. The supernatant $(3-5 \mu \mathrm{l})$ was injected into the HPLC system. The chromatography system consisted of an LC-4C amperometric detector with a cross-flow detector cell (BAS, IN, USA), an Ultimate 3000 pump (Thermo Scientific, USA), and a Hypersil Gold analytical column ( $3 \mu \mathrm{m}$, $100 \times 3 \mathrm{~mm}$, Thermo Scientific, USA). The mobile phase consisted of $0.1 \mathrm{M} \mathrm{KH}_{2} \mathrm{PO}_{4}, 0.5 \mathrm{mM} \mathrm{Na} 2$ EDTA, $80 \mathrm{mg} / 1$ sodium 1-octanesulfonate, and a $4 \%$ methanol, adjusted to $\mathrm{pH} 3.7$ with an $85 \% \mathrm{H}_{3} \mathrm{PO}_{4}$. The flow rate was $1 \mathrm{ml} / \mathrm{min}$. The potential

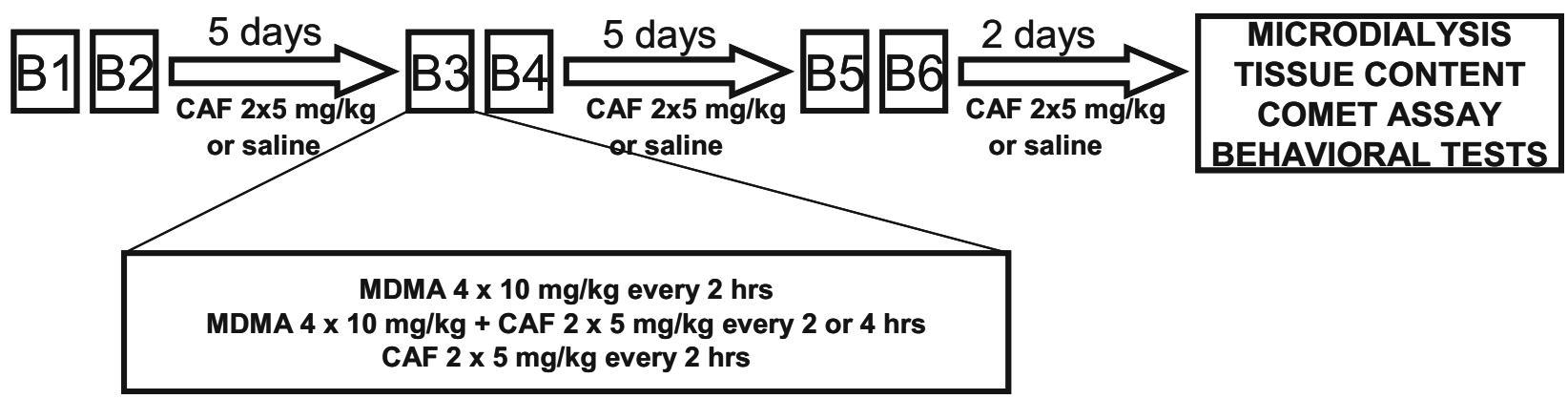


of a 3-mm glassy carbon electrode was set at $0.7 \mathrm{~V}$ with sensitivity of $5 \mathrm{nA} / \mathrm{V}$. The temperature of the column was maintained at $30{ }^{\circ} \mathrm{C}$. The Chromax 2007 program (Pol-Lab, Warszawa, Poland) was used for data collection and analysis.

\section{Comet Assay}

\section{Preparation of Nuclear Suspension}

Animals were killed 60 days after termination of drug treatments. The whole cortex was separated in anatomical borders. Next, the brain tissue was minced with surgical scalpel and homogenized in a manual homogenizer with homogenizing solution containing $0.25 \%$ Triton. The homogenate was filtered and centrifuged at $850 \times \mathrm{g}$ for $10 \mathrm{~min}$. The supernatant was discarded while the pellet was resuspended in the same volume of homogenization medium without Triton and centrifuged at $850 \times \mathrm{g}$ for $10 \mathrm{~min}$. The sediment was washed once more in the same way and centrifuged at $600 \times g$ for $8 \mathrm{~min}$. The pellet was resuspended in $0.8 \mathrm{ml}$ of homogenization solution without Triton, mixed with $4.2 \mathrm{ml}$ of purification medium, and centrifuged at $19,000 \times g$ for $45 \mathrm{~min}$. The nuclei were obtained as a transparent sediment at the bottom. The pellet was resuspended in $0.5 \mathrm{ml}$ of $2.0 \mathrm{M}$ sucrose and was layered over a sucrose gradient (2.6 and $2.4 \mathrm{M}$ bottom to top). The gradient was allowed to stand for $3 \mathrm{~h}$ at $0{ }^{\circ} \mathrm{C}$ before use. Nuclear fractionation was obtained by centrifugation at $19,000 \times \mathrm{g}$ for $45 \mathrm{~min}$.

\section{Alkaline Comet Assay}

The nuclei were added to a tube with $200 \mu \mathrm{l}$ of PBS (without $\mathrm{Ca}^{++}$and $\mathrm{Mg}^{++}$) and mixed gently. The suspension was mixed with LMA agarose and transferred immediately onto Comet slides. The slides were placed at $4{ }^{\circ} \mathrm{C}$ in the dark for $10 \mathrm{~min}$. Then, the slides were immersed in pre-chilled lysis solution and left at $4{ }^{\circ} \mathrm{C}$ in the dark for $30 \mathrm{~min}$. The buffer was drained, and the slides were immersed in alkaline unwinding solution and were left for $45 \mathrm{~min}$ in the dark. Next, electrophoresis was run at $21 \mathrm{~V}$ for $30 \mathrm{~min}$. After electrophoresis, the slides were washed first with $\mathrm{H}_{2} \mathrm{O}$ then with $70 \%$ ethanol and dried at $45{ }^{\circ} \mathrm{C}$ for $10 \mathrm{~min}$. The slides were then covered with dye and allowed to dry completely at room temperature in the dark. On the next day, the slides were examined under a fluorescent microscope. DNA damage was presented as an olive tail moment. Olive tail moment is defined as the product of the tail length and the fraction of total DNA in the tail. Tail moment incorporates a measure of both the smallest detectable size of migrating DNA (reflected in the comet tail length) and the number of damaged pieces (represented by the intensity of DNA in the tail). The value of olive tail moment was calculated according to the following formula: olive tail moment $=\left(\right.$ tail $_{\text {mean }}-$ head $\left._{\text {mean }}\right) \times$ tail\%DNA/100.

\section{Prodynorphin and Proenkephalin Levels in the Mouse Striatum}

\author{
Tissue Collection and RNA Isolation
}

Brains were removed from the skull, and tissue samples including the striatum were collected. Samples were placed in individual tubes with the tissue storage reagent RNAlater (Qiagen Inc., Valencia, CA, USA) and stored at $-70^{\circ} \mathrm{C}$ until RNA isolation. Samples were thawed at room temperature and homogenized in $1 \mathrm{ml}$ of Trizol reagent (Invitrogen, Carlsbad, CA, USA). RNA isolation was performed in accordance with the manufacturer's protocol. The total RNA concentration was measured using a NanoDrop ND-1000 spectrophotometer (NanoDrop Technologies Inc., Montchanin, DE, USA). Reverse transcription (RT) was performed on $1000 \mathrm{ng}$ of total RNA using Omniscript reverse transcriptase (Qiagen Inc.) at $37^{\circ} \mathrm{C}$ for $60 \mathrm{~min}$. Reverse transcriptase reactions were performed in the presence of an RNase inhibitor (rRNAsin; Promega, Madison, WI, USA) and oligo (dT)1218 primer (Invitrogen).

\section{Quantitative PCR}

The qPCR reactions were performed using assay-on-demand TaqMan probes, hypoxanthine guanine phosphoribosyltransferase (HPRT) (Mm00446968_m1), PDYN (prodynorphin Mm0045753_m1), and PENK (proenkephalin Mm01212875_m1; Applied Biosystems, Carlsbad, CA, USA), and were run on the CFX96 Touch real-time PCR machine (BioRad, Hercules, CA, USA). The expression of the HPRT1 transcript was quantified at a stable level between the experimental groups to control for variations in cDNA amounts. Cycle threshold values were calculated automatically by iCycler IQ 3.0 software with default parameters. Abundance of RNA was calculated as $2-$ (threshold cycle).

\section{DAT and SERT Densities in the Mouse Striatum}

\section{Immunohistochemistry Studies}

Tissue Preparation Coronal brain sections were cut at $50 \mu \mathrm{m}$ on a vibratome and stored in a cryoprotectant solution at $-20{ }^{\circ} \mathrm{C}$ until use. For each mouse, three sections were collected from each of the brain regions analyzed at the following coordinates: from 2.22 to $1.78 \mathrm{~mm}$ (frontal cortex) and from 1.34 to $0.74 \mathrm{~mm}$ (striatum) relative to bregma, according to the mouse brain atlas of Paxinos and Franklin (2008).

Reaction Protocols Free-floating sections were rinsed in $0.1 \mathrm{M}$ phosphate buffer (PB), blocked in a solution containing 3\% normal donkey serum (Jackson ImmunoResearch Europe, 
Suffolk, UK) and $0.3 \%$ Triton X-100 in $0.1 \mathrm{M}$ PB at room temperature for $2 \mathrm{~h}$, and incubated in the same solution with the primary antibody (monoclonal rat anti-DAT antibody diluted 1:1000, Millipore, Temecula, CA, USA; polyclonal rabbit anti-SERT antibody diluted 1:1000, Chemicon, Temecula, CA, USA) for two nights. After completion of incubation with the primary antibody, sections were rinsed three times in $0.1 \mathrm{M} \mathrm{PB}$ and incubated with the secondary antibody (AlexaFluor® 594labeled donkey anti-rabbit diluted 1:400 and AlexaFluor® 488labeled donkey anti-rat diluted 1:400, Jackson ImmunoResearch Europe, Suffolk, UK) in $0.1 \mathrm{M}$ PB at room temperature for $2 \mathrm{~h}$. After incubation with the secondary antibody, sections were rinsed and immediately mounted onto glass slides coated with gelatin in Mowiol mounting medium.

Image Analysis Images of single wavelengths were obtained with an epifluorescence microscope (Axio Scope A1, Zeiss, Oberkochen, Germany) connected with a digital camera (1.4 MPixels, Infinity 3-1, Lumenera, Nepean, Canada). In each of the three brain sections, two portions from the striatum (dorsolateral and ventromedial) or the prelimbic/infralimbic areas of the medial prefrontal cortex (mPFC), left and right, were acquired using a $\times 20$ objective. For both DAT and SERT immunoreactivities in the striatum and $\mathrm{mPFC}$, the density of immunoreacted fibers was determined quantitatively using the ImageJ software (US National Institutes of Health, USA). Sections were captured in black and white 8-bit monochrome, and the density of fibers was determined in fixed regions using a threshold level that was kept constant across all images. The pixels were converted into square micrometers by employing a suited calibration, in order to represent the area occupied by a specific immunoreaction product in square micrometers. The final values are expressed as a percentage of the respective vehicle group. No significant differences in the density of immunoreacted fibers were seen between the three coronal sections. For each level of the striatum and $\mathrm{mPFC}$, the obtained value was first normalized with respect to the vehicle, then, values from different levels were averaged.

\section{Behavioral Tests}

\section{Exploratory and Locomotor Activities in the Open-Field Test}

The test was performed using a black PCV box $(67 \mathrm{~cm} \times 57 \mathrm{~cm} \times 30 \mathrm{~cm}$, length $\times$ width $\times$ height $)$ divided into six symmetrical sectors. The arena was dimly illuminated with an indirect light of $18 \mathrm{~lx}$. Each experiment was carried out during the light phase of the light/dark cycle. The mice were selected from separate housing cages. Each mouse was diagonally placed in the middle of the box. The behavior of the animals (line crossing, center square duration, rearing, stretch attend postures) was measured over a 5-min period. The test box was wiped clean between each trial.

\section{Novel Object Recognition Test}

New object recognition test in mice was carried out using a wooden, black, round "free-field," placed $80 \mathrm{~cm}$ above the floor with a diameter of $100 \mathrm{~cm}$ and divided into eight equal sectors with white line. The laboratory room was dark, and only the center of the open field was illuminated with a $25-\mathrm{W}$ bulb placed $75 \mathrm{~cm}$ above the platform. On the first day of the experiment (adaptation), mice were placed in the open field for $10 \mathrm{~min}$. On the next day, the animals were placed in the open field for $5 \mathrm{~min}$ with two identical objects (white tin, $5 \mathrm{~cm}$ wide and $14 \mathrm{~cm}$ high or green pyramid $5 \mathrm{~cm}$ wide and $14 \mathrm{~cm}$ high). The time of object interest was measured for each of the two objects separately. Then, $1 \mathrm{~h}$ after the first session, the mice were again placed in a free field for $5 \mathrm{~min}$ with two different objects, one from the previous session (old) and the other new (white box and green pyramid). The time of object interest was measured for each of the two objects separately (sniffing, touching, or climbing).

\section{Data Analysis}

All obtained microdialysis data were presented as a percent of the basal level assumed to be $100 \%$. The statistical significance was calculated using a repeated-measure ANOVA or where appropriate a one-way ANOVA, followed by Tukey's post hoc test. The results were considered statistically significant when $P<0.05$.

\section{Results}

\section{The Effect of Repeated "Binge" Administration of MDMA, Caffeine, and Their Combination on the Extracellular Level of DA and 5-HT in the Mouse Striatum}

Caffeine at doses of $5 \mathrm{mg} / \mathrm{kg}$ given twice daily 2 hours apart did not affect significantly the basal extracellular DA level (Fig. 1a). MDMA (10 mg/kg) given four times daily 2 hours apart significantly increased extracellular DA level with a maximum after the third injection (Fig. 1a). Co-administration of both drugs produced a significantly stronger effect on extracellular DA level than each of the drugs given separately (Fig. 1a). Repeated-measure ANOVA showed a significant effect of treatment groups $\left[F_{3,12}=158, P<0.0001\right]$, sampling period $\left[F_{15,180}=48, P<0.0001\right]$, and the interaction between treatment groups and sampling period $\left[F_{45,180}=25, P<0.0001\right]$. The caffeine-induced enhancement of MDMA action on DA release is presented by the total effect expressed as an area under the curve (AUC) in Fig. 1c.

Caffeine given twice daily every 2 hours at a dose of $5 \mathrm{mg} /$ $\mathrm{kg}$ markedly increased extracellular 5-HT level in the mouse 
striatum (Fig. 1b). MDMA (10 mg/kg) administered four times a day every 2 hours increased extracellular 5-HT level to a similar extent as caffeine. However, the increase produced by a combination of both drugs was weaker as compared to the effect of MDMA or caffeine given separately (Fig. 1b). Repeated-measure ANOVA showed a significant effect of treatment groups $\left[F_{3,12}=354, P<0.0001\right]$, sampling period $\left[F_{15,180}=25, P<0.0001\right]$, and the interaction between treatment groups and sampling period $\left[F_{45,180}=16, P<0.0001\right]$.
The MDMA-induced decrease in the caffeine effect on 5-HT release is shown as an AUC in Fig. 1d.

\section{The Effect of Caffeine on MDMA-Induced Increase in the Extracellular Level of DA and 5-HT in the Mouse} Striatum After Acute and Chronic Drug Administrations

MDMA at an acute dose of $20 \mathrm{mg} / \mathrm{kg}$ increased DA release to ca. $800 \%$ of the basal level at $60 \mathrm{~min}$, but the DA release
Fig. 1 The effect of repeated administration of CAF $(2 \times 5 \mathrm{mg} /$ $\mathrm{kg})$, MDMA $(4 \times 10 \mathrm{mg} / \mathrm{kg})$, and their combination on the extracellular level of DA and 5HT in the mouse striatum. Time of drug injections is indicated with thick arrows. a, b Timecourse. c, $\mathbf{d}$ Total effect expressed as an area under the curve (AUC). Values are presented as the mean $\pm \operatorname{SEM}(n=4$ animals per group). Basal extracellular levels of DA and 5-HT were as follows $(\mathrm{pg} / 10 \mu \mathrm{l})$ : control $1.18 \pm 0.06$ and $1.67 \pm 0.25$, CAF $1.42 \pm 0.18$ and $1.28 \pm 0.18$, MDMA $2.1 \pm 0.23$ and $1.27 \pm 0.15$, and MDMA plus CAF $1.92 \pm 0.19$ and $1.08 \pm 0.09$, respectively. $* P<0.0002$ vs. control group; "a," $<0.0002$ difference vs. MDMA; "b," < 0.002 difference vs. CAF (a, b Repeated-measure ANOVA. c, d One-way ANOVA and Tukey's post hoc test) a
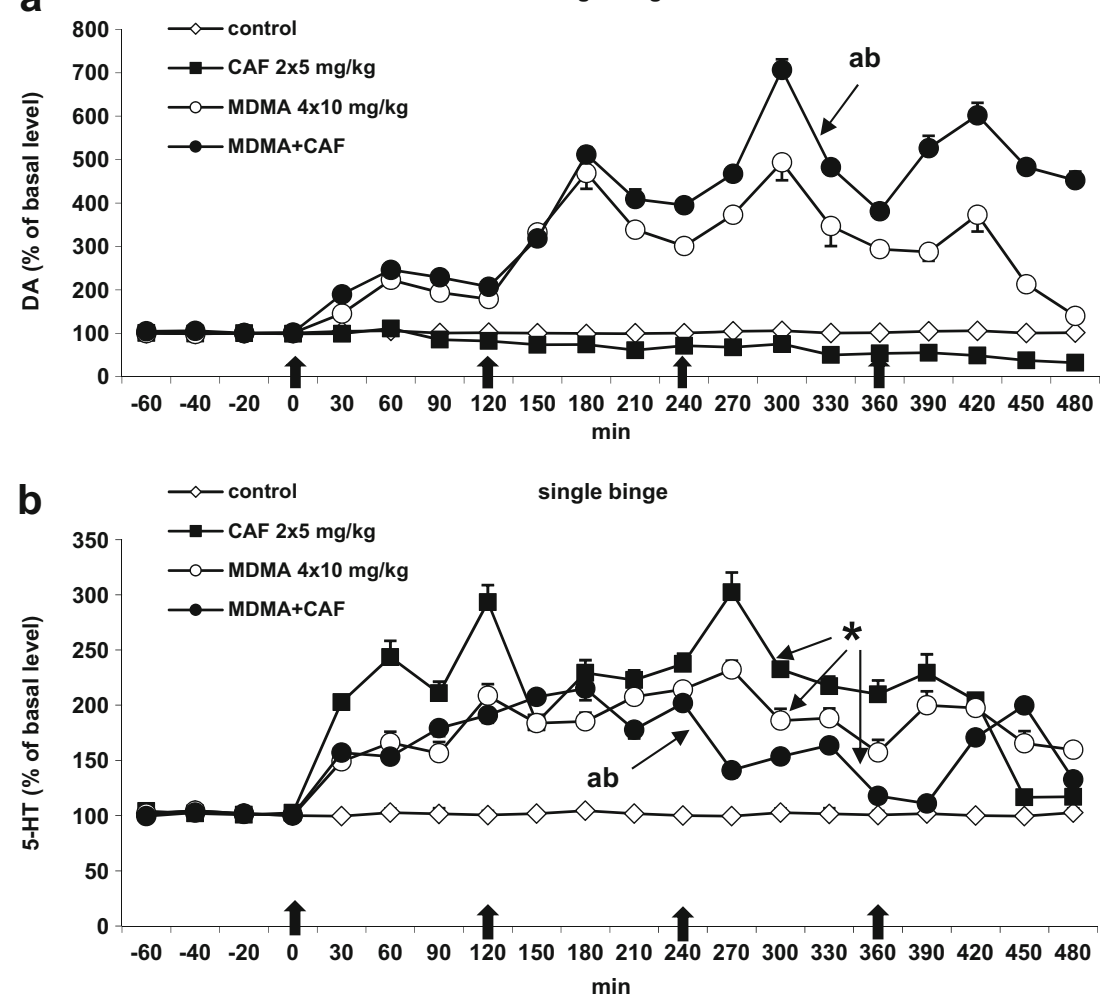

C
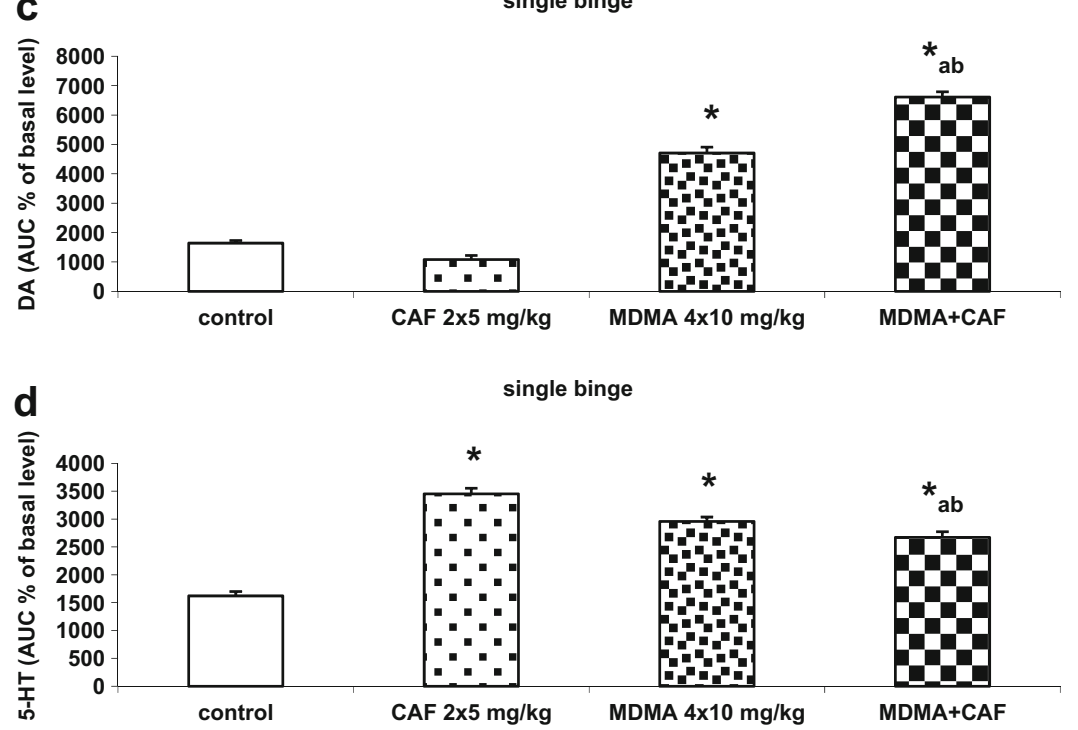
returned to the control values beginning from $210 \mathrm{~min}$ after administration $(P<0.0002)$. Caffeine at an acute dose of $10 \mathrm{mg} / \mathrm{kg}$ slightly, but significantly, increased DA release and when injected jointly with MDMA shifted the maximum of DA increase to $150 \mathrm{~min}$ and prolonged the MDMAinduced increase in DA level until the end of fraction collection time, i.e., $360 \mathrm{~min}$ (Fig. 2a). Repeated-measure ANOVA showed a significant effect of treatment groups $\left[F_{3,14}=1311\right.$, $P<0.0001]$, sampling period $\left[F_{11,154}=232, P<0.0001\right]$, and the interaction between treatment groups and sampling period $\left[F_{33,54}=215, P<0.0001\right]$.

The increase in 5-HT release induced by MDMA at an acute dose of $20 \mathrm{mg} / \mathrm{kg}$ was maximal at $60 \mathrm{~min}$ after injection, and 5HT level gradually decreased reaching control values at 300 min of fraction collection. Caffeine at an acute dose of $10 \mathrm{mg} / \mathrm{kg}$ slightly but significantly increased 5-HT release and when given jointly with MDMA shifted the maximum MDMA effect to $120 \mathrm{~min}$ and prolonged the increase in 5-HT release induced by MDMA until 360 min of fraction collection (Fig. $2 \mathrm{~b})$. Repeated-measure ANOVA showed a significant effect of treatment groups $\left[F_{3,16}=260, P<0.0001\right]$, sampling period $\left[F_{11,176}=66, P<0.0001\right]$, and the interaction between treatment groups and sampling period $\left[F_{33,176}=41, P<0.0001\right]$.

The maximal increase in DA release in response to the challenging MDMA dose of $20 \mathrm{mg} / \mathrm{kg}$ in animals treated chronically with the drug was lower than that produced by a single dose and amounted to ca. $400 \%$ of the basal level (Fig. 2c). Caffeine given chronically did not affect DA release, while it enhanced MDMA effect to ca. $700 \%$ of the basal level at $60 \mathrm{~min}$ after injection of the challenging dose of $10 \mathrm{mg} / \mathrm{kg}$ (Fig. 2c). Repeated-measure ANOVA showed a significant effect of treatment groups $\left[F_{3,14}=178, P<0.0001\right]$, sampling period $\left[F_{11,154}=96\right.$, $P<0.0001]$, and the interaction between treatment groups and sampling period $\left[F_{33,154}=44, P<0.0001\right]$.

The challenging dose of MDMA $(20 \mathrm{mg} / \mathrm{kg}$ ) potently increased 5-HT release in animals treated chronically with MDMA $(P<0.0002)$. The increase in 5-HT release to ca. $2500 \%$ of the basal level was maximal at $60 \mathrm{~min}$ after injection of the drug (Fig. 2d). The challenging dose of caffeine $(10 \mathrm{mg} / \mathrm{kg})$ did not affect 5 -HT release in animals treated chronically with this drug, but caffeine inhibited the effect of the challenging dose of MDMA ( $20 \mathrm{mg} / \mathrm{kg})$ on 5 -HT release in animals treated chronically with MDMA plus caffeine (Fig. 2d). Repeated-measure ANOVA showed a significant effect of treatment groups $\left[F_{3,20}=184, P<0.0001\right]$, sampling period $\left[F_{11,220}=66, P<0.0001\right]$, and the interaction between treatment groups and sampling period $\left[F_{33,220}=40, P<0.0001\right]$.

The basal extracellular DA level in the striatum of animals receiving repeated doses of caffeine was significantly $(P<0.0001)$ increased from $2.49 \pm 0.21 \mathrm{pg} / 10 \mu \mathrm{l}$ (in control) to $6.98 \pm 1.21 \mathrm{pg} / 10 \mu \mathrm{l}$ of dialysate fraction. In animals receiving repeated doses of MDMA, the basal extracellular level of DA was $4.52 \pm 0.87(P<0.0001$ vs. control), while in the group treated chronically with MDMA and caffeine, the basal extracellular DA level was $5.24 \pm 0.15(P<0.0001$ vs. control) and was not significantly different from the level in groups receiving the drugs separately.

The basal extracellular level of 5-HT was decreased from $1.25 \mathrm{pg} / 10 \mu \mathrm{l}$ in the control group to $0.18 \mathrm{pg} / 10 \mu \mathrm{l}$ in the striatum of animals receiving repeated doses of caffeine $(P<0.0001)$. Similarly, chronic administration of MDMA elicited a decrease in 5-HT basal level to $0.19 \mathrm{pg} / 10 \mu \mathrm{l}(P<0.0001)$. 5-HT basal level in the group receiving chronically the combination of both drugs was decreased to $0.54 \pm 0.05 \mathrm{pg} / 10 \mu \mathrm{l}(P<0.0001)$.

Table 1 shows the comparison of the total effect expressed as an AUC in DA and 5-HT release induced by acute and chronic administrations of MDMA and caffeine. It is clear that the effect of the challenging doses of both psychostimulant drugs on DA release was weaker in groups pretreated chronically with caffeine and MDMA vs. their acute doses. In contrast, the effect of the challenging doses of caffeine and MDMA on 5-HT release was stronger in animals receiving chronic treatment of psychostimulants vs. their single doses.

\section{The Effect of Chronic Treatment with Caffeine and MDMA on Tissue Content of DA, DOPAC, HVA, 5-HT, and 5-HIAA in the Mouse Striatum and Frontal Cortex}

Chronic treatment with caffeine and MDMA significantly $(P<0.001)$ increased DA content in the mouse striatum, but not in the frontal cortex (Table 2). The increase in DA tissue content was higher in the group treated concomitantly with caffeine and MDMA than in animals receiving these drugs separately (Table 2). Striatal DOPAC tissue level was decreased by caffeine and MDMA, but their combination significantly $(P<0.001)$ reversed this decrease (Table 2$)$. MDMA decreased also DOPAC content in the mouse frontal cortex $(P<0.001)$, but in contrast to the striatum, the decrease in DOPAC tissue level was potentiated $(P<0.001)$ by the combination of caffeine and MDMA (Table 2). 5-HT content was not changed by both psychostimulants and their combination either in the striatum or in the frontal cortex (Table 2). MDMA significantly $(P<0.001)$ decreased the tissue level of 5-HIAA in the striatum and frontal cortex. The decrease in the serotonin metabolite was further potentiated $(P<0.001)$ by the combination of caffeine and MDMA in the striatum, but not in the frontal cortex (Table 2).

\section{The Effect of Chronic Treatment with Caffeine and MDMA on the Density of DAT and SERT in the Mouse Striatum and Frontal Cortex}

MDMA given chronically significantly $(P<0.001)$ decreased dopamine and serotonin transporter (DAT and SERT, respectively) densities in the mouse striatum as well as in the frontal 
Fig. 2 The effect of CAF (10 mg/ $\mathrm{kg})$, MDMA (20 $\mathrm{mg} / \mathrm{kg})$, and their combination on the extracellular level of DA and 5HT in the mouse striatum in animals treated chronically with saline (acute) or CAF, MDMA, and MDMA plus CAF (chronic). a-d Time-course. Values are presented as the mean $\pm \operatorname{SEM}(n=4-8$ animals per group). $* P<0.0002$ represents a significant difference in comparison to the control group; "a," < 0.002 difference between MDMA and MDMA plus CAF; "b," < 0.0002 difference between CAF and MDMA plus CAF (repeated-measure ANOVA and Tukey's post hoc test)
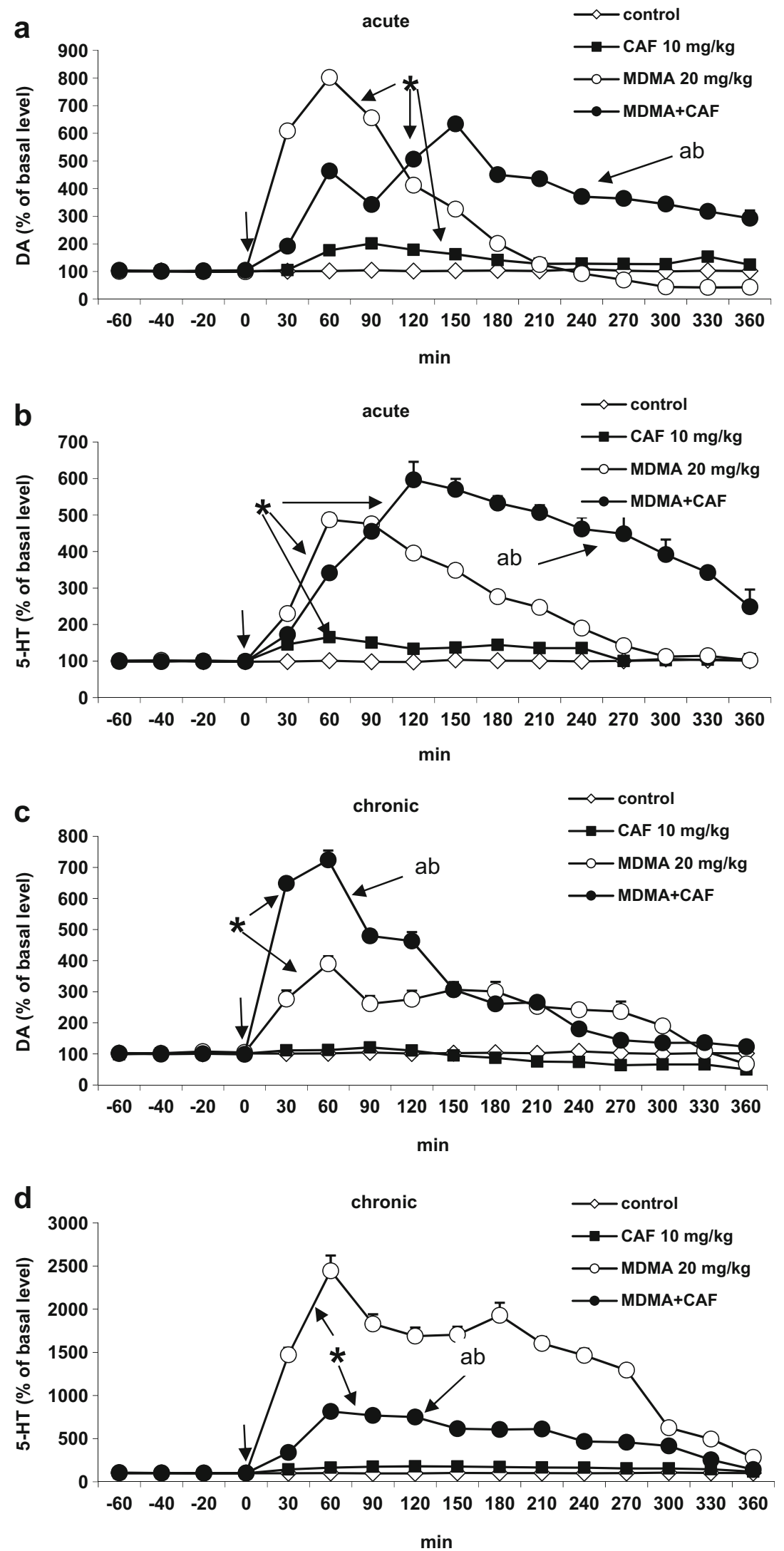
Table 1 A comparison of the response to a challenging dose of drugs in animals treated repeatedly with saline (control) or chronically with CAF, MDMA, and MDMA plus CAF with respect to the extracellular levels of DA and 5-HT in the mouse striatum

\begin{tabular}{llllll}
\hline Treatment (mg/kg) & \multicolumn{2}{l}{$\begin{array}{l}\text { DA (AUC \% of basal level, } \\
\text { mean } \pm \text { SEM) }\end{array}$} & & \multicolumn{2}{l}{$\begin{array}{l}\text { 5-HT (AUC \% of basal level, } \\
\text { mean } \pm \text { SEM) }\end{array}$} \\
\cline { 2 - 3 } \cline { 5 - 6 } & Control & Chronic & & Control & Chronic \\
\hline Saline & $1232 \pm 15$ & $1130 \pm 28$ & & $1208 \pm 31$ & $1047 \pm 38$ \\
CAF 10 & $1752 \pm 33$ & $1034 \pm 23^{*}$ & & $1558 \pm 22$ & $1908 \pm 18^{*}$ \\
MDMA 20 & $3421 \pm 52$ & $2909 \pm 148^{*}$ & & $3121 \pm 61$ & $16,831 \pm 820^{*}$ \\
MDMA 20 + CAF 10 & $4712 \pm 33$ & $3868 \pm 78^{*}$ & & $5069 \pm 217$ & $6239 \pm 191^{*}$ \\
\hline
\end{tabular}

Values are the mean \pm SEM and express an area under the curve (AUC) of the percent of basal level $* P<0.001$ control vs. chronic administration (one-way ANOVA and Tukey's post hoc test) cortex (Table 3). The combination of caffeine and MDMA significantly $(P<0.001)$ reversed MDMA-induced decrease in DAT in the mouse striatum while potentiating $(P<0.001)$ the MDMA-induced decrease in SERT in the mouse frontal cortex (Table 3). Caffeine had no influence on DAT and SERT densities in both brain regions (Table 3).

\section{The Effect of Acute and Chronic Treatments with Caffeine and MDMA on the Oxidative Damage of DNA in the Mouse Cortex}

Caffeine and MDMA given acutely or chronically produced oxidative damage of DNA in nuclei from the mouse cortex as measured 2 months after cessation of treatment (Fig. 3a, b). The damage of DNA was stronger after combination of both drugs administered acutely or chronically (Fig. 3a, b). The extent of DNA damage was smaller after all treatments when it was measured $24 \mathrm{~h}$ after termination of drug administration (data not shown).

\section{PDYN and PENK Gene Expressions in the Mouse Striatum After Chronic Treatment with Caffeine and MDMA}

The $P d y n$ mRNA level was significantly increased $(P<0.0001)$ while the Penk mRNA remained unchanged in the mouse striatum after chronic administration of MDMA (Fig. 4a, b). Caffeine alone significantly $(P<0.05)$ increased the Pdyn but not Penk mRNA levels (Fig. 4a, b). The effect of caffeine and MDMA combination on PDYN gene expression did not differ from the effect of MDMA.

\section{The Effect of Chronic Treatment with Caffeine and MDMA on Exploratory and Locomotor Activities in the Open-Field and Novel Object Recognition Test}

MDMA given chronically significantly $(P<0.01)$ decreased the locomotor activity of mice as shown by the decreased time of walking and number of sector crossings in the open field test (Fig. 5a). Caffeine did not

Table 2 Tissue content of DA, DOPAC, HVA, 5-HT, and 5-HIAA in the mouse striatum and frontal cortex measured $3 \mathrm{~h}$ after cessation of treatment with drugs

\begin{tabular}{|c|c|c|c|c|c|}
\hline Treatment & DA & DOPAC & HVA & $5-\mathrm{HT}$ & 5-HIAA \\
\hline \multicolumn{6}{|c|}{ Striatum $(\mathrm{pg} / \mathrm{mg} w \mathrm{w}) \pm \operatorname{SEM}(n)$} \\
\hline Control & $9206 \pm 568(11)$ & $913 \pm 40(11)$ & $1016 \pm 31(11)$ & $458 \pm 30(11)$ & $353 \pm 16(11)$ \\
\hline $\mathrm{CAF}$ & $10,929 \pm 728(11)^{*}$ & $631 \pm 44(11)^{*}$ & $1141 \pm 95(11)$ & $495 \pm 33(11)$ & $362 \pm 19(11)$ \\
\hline MDMA & $11,175 \pm 740(11)^{*}$ & $447 \pm 28(11)^{*}$ & $962 \pm 35(11)$ & $435 \pm 26(11)$ & $238 \pm 11(11)^{*}$ \\
\hline $\mathrm{CAF}+\mathrm{MDMA}$ & $16,292 \pm 2246(5)^{* * * * * * * *}$ & $595 \pm 74(5)^{* * * *}$ & $1169 \pm 142(5)$ & $447 \pm 55(5)$ & $191 \pm 18(5)^{* * * * * * * *}$ \\
\hline \multicolumn{6}{|c|}{ Frontal cortex $(\mathrm{pg} / \mathrm{mg} \mathrm{wt}) \pm \operatorname{SEM}(n)$} \\
\hline Conrol & $1086 \pm 90(11)$ & $133 \pm 10(11)$ & $221 \pm 13(11)$ & $450 \pm 24(11)$ & $154 \pm 7(4)$ \\
\hline CAF & $1215 \pm 121(11)$ & $130 \pm 11(11)$ & $238 \pm 14(11)$ & $435 \pm 20(11)$ & $160 \pm 10(11)$ \\
\hline MDMA & $1284 \pm 80(11)$ & $106 \pm 8(11)^{*}$ & $219 \pm 15(11)$ & $453 \pm 44(11)$ & $129 \pm 12(11)^{*}$ \\
\hline $\mathrm{CAF}+\mathrm{MDMA}$ & $1224 \pm 160(4)$ & $81 \pm 6(11)^{* * * * * * *}$ & $205 \pm 14(4)$ & $496 \pm 33(4)$ & $130 \pm 2(4)^{*}$ \\
\hline
\end{tabular}

Values are the mean $\pm \operatorname{SEM}(n)$

$* P<0.001$ vs. control; $* * P<0.001$ vs. MDMA; $* * * P<0.001$ vs. CAF (one-way ANOVA and Tukey's post hoc test) 
Table 3 The density of dopamine transporter (DAT) and serotonin transporter (SERT) in the mouse striatum and frontal cortex measured after cessation of treatment with the drugs

\begin{tabular}{lll}
\hline Treatment & \multicolumn{1}{l}{ DAT } & \multicolumn{1}{l}{ SERT } \\
\hline Striatum density \pm SEM $(n)$ & \\
Control & $147.7 \pm 3.4(5)$ & $31.7 \pm 2.5(5)$ \\
CAF & $134.5 \pm 4.6(4)$ & $33.0 \pm 0.9(4)$ \\
MDMA & $112.4 \pm 7.8(7)^{*}$ & $21.7 \pm 1.5(8)^{*}$ \\
CAF+MDMA & $137.2 \pm 6.9(7)^{* *}$ & $22.1 \pm 1.9(9)^{*}$ \\
Frontal cortex density \pm SEM $(n)$ & \\
Control & $14.0 \pm 2.5(6)$ & $21.2 \pm 3.7(6)$ \\
CAF & $17.9 \pm 3.3(4)$ & $23.2 \pm 0.6(4)$ \\
MDMA & $11.1 \pm 0.6(10)^{*}$ & $16.6 \pm 2.1(10)^{*}$ \\
CAF+MDMA & $11.4 \pm 1.1(8)^{*}$ & $9.5 \pm 1.0(8)^{* * * * * * *}$ \\
\hline
\end{tabular}

The data are the mean $\pm \operatorname{SEM}(n)$ and express the density of grey values $* P<0.001$ vs. control; $* * P<0.001$ vs. MDMA; $* * * P<0.001$ vs. CAF (one-way ANOVA and Tukey's post hoc test) affect those parameters. On the other hand, MDMA did not change the time spent by mice on an exploration of the novel object in the novel object recognition test, but when given with caffeine, it significantly decreased this time as compared with control and MDMA-alone groups $(P<0.01$, Fig. 5 b).

\section{Discussion}

Here, we provide an insight into the synergistic interaction between MDMA and caffeine after the "weekend" mode of drug administration in mice. Our findings indicate that caffeine increased the response of DA neurons to the challenging dose of MDMA while decreasing the response of serotonergic neurons. Caffeine potentiated the oxidative damage of nuclear DNA induced by MDMA and had no effect on MDMA-induced decrease in DAT density in the frontal cortex; however, it reversed MDMA-induced DAT decrease in the striatum. Furthermore, caffeine potentiated the decrease in SERT density produced by MDMA in the
Fig. 3 The effect of acute treatment of animals with $\mathrm{CAF}$ $(10 \mathrm{mg} / \mathrm{kg})$, MDMA (20 mg/kg), and their combination (a) or chronic administration of CAF, MDMA, and MDMA plus CAF (b) on the oxidative damage of DNA in nuclei from the mouse cortex 2 months after cessation of treatment. Values are presented as the mean $\pm \operatorname{SEM}(n=4-8$ animals per group). Data represent an olive tail moment. Olive tail moment is defined as the product of the tail length and the fraction of total DNA in the tail. Tail moment incorporates a measure of both the smallest detectable size of migrating DNA (reflected in the comet tail length) and the number of damaged pieces (represented by the intensity of DNA in the tail). The loss of

DNA integrity persisted 60 days after drug administration. $* P<0.01$ in comparison to control, "a," "b" $<0.01$ in comparison to MDMA or CAF groups, respectively (one-way ANOVA and Tukey's post hoc test)
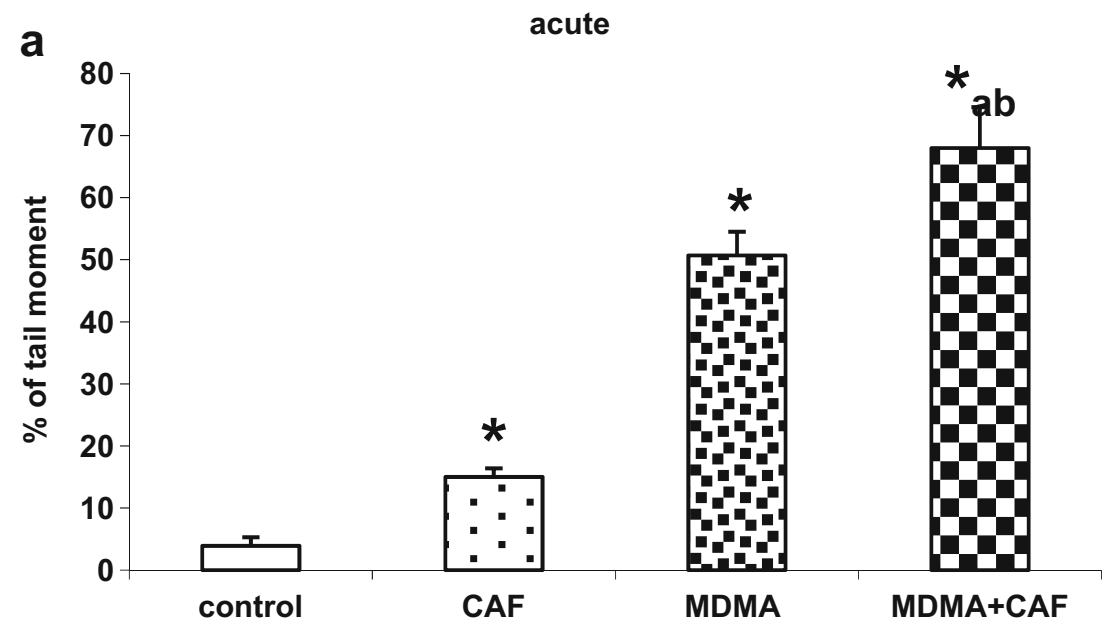

b

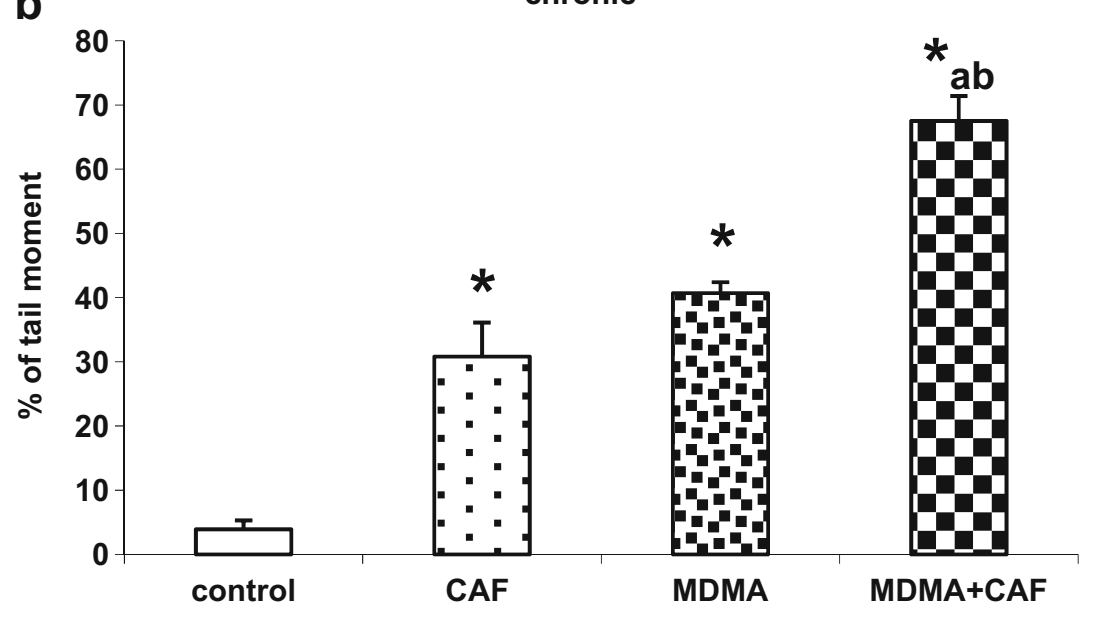


Fig. 4 Quantitative real-time PCR analysis of PDYN (a) and PENK (b) gene expressions in the mouse striatum after chronic administration of CAF, MDMA, and MDMA plus CAF. Values are presented as the mean \pm SEM ( $n=4-10$ animals per group). Data represent mRNA levels with respect to the control group. $* P<0.05$; $* * P<0.001$ in comparison to control (one-way ANOVA and Tukey's post hoc test) a

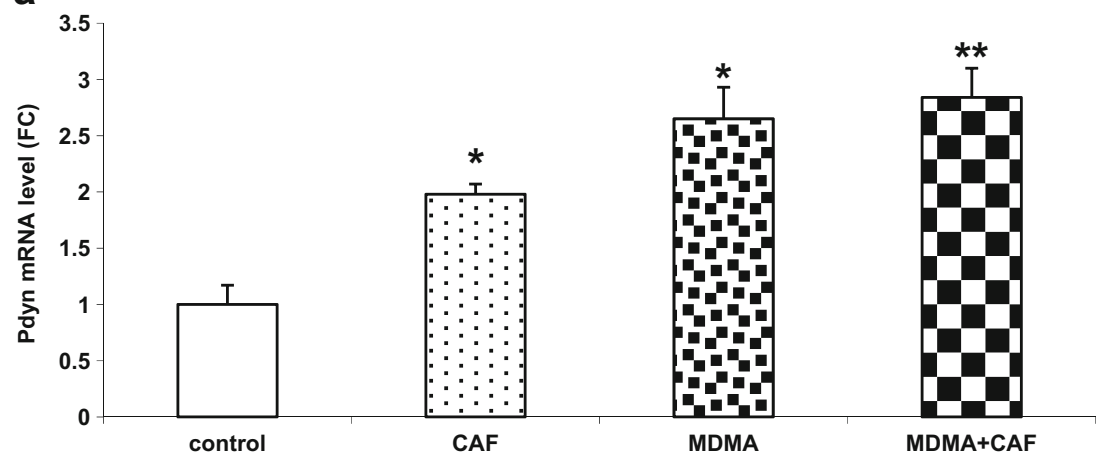

b

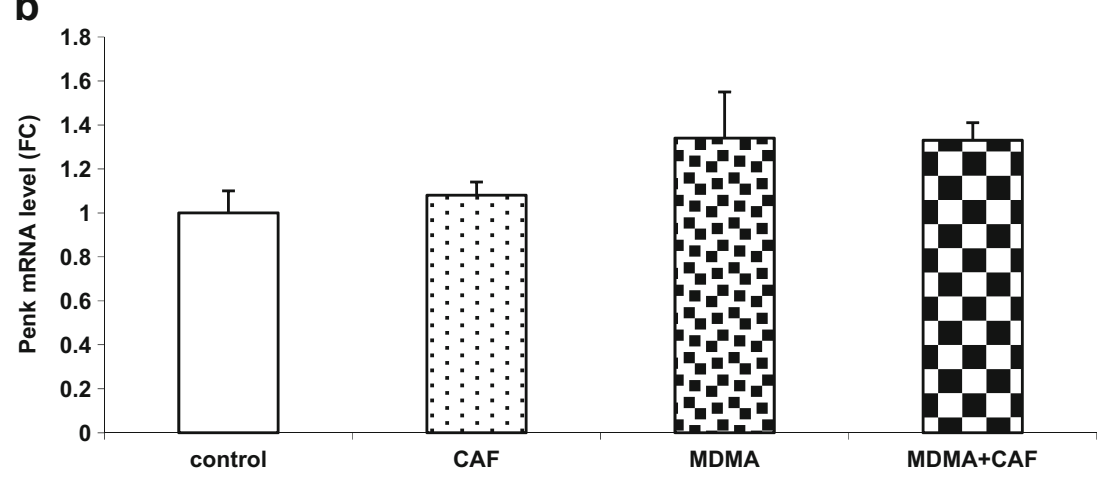

frontal cortex. Striatal PDYN expression increased by MDMA was not affected by caffeine. Furthermore, exploratory and locomotor activities of mice decreased by MDMA were not affected by caffeine, but exploration of novel object in the NOR test was diminished in animals treated with MDMA and caffeine.

\section{MDMA Effect on DA and 5-HT Release}

In the present study, we report that MDMA produced longlasting changes in striatal DA and 5-HT release in mice. MDMA used in four repeated sub-maximal doses of $10 \mathrm{mg} / \mathrm{kg}$ increased DA and 5-HT release in the mouse striatum to a
Fig. 5 The effect of chronic administration of CAF, MDMA, and MDMA plus CAF on exploratory and locomotor activities in the open-field (a) and novel object recognition (b) tests. Values are presented as the mean \pm SEM $(n=10-20$ animals per group). Bars represent the time of walking and number of crossings (a), and time of exploration of novel object (b).

$* P<0.01$ in comparison to control; "a," "b" < 0.01 in comparison to MDMA or CAF groups, respectively (one way ANOVA and Tukey's post hoc test)

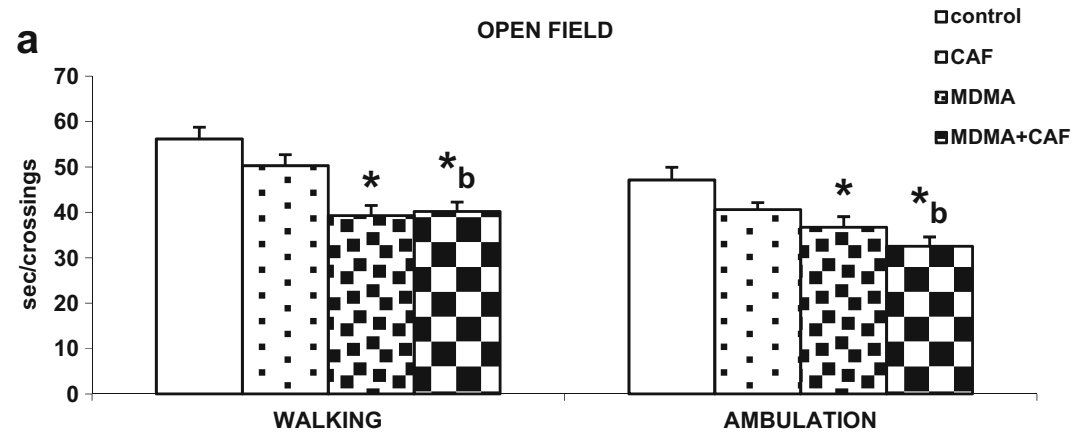

b

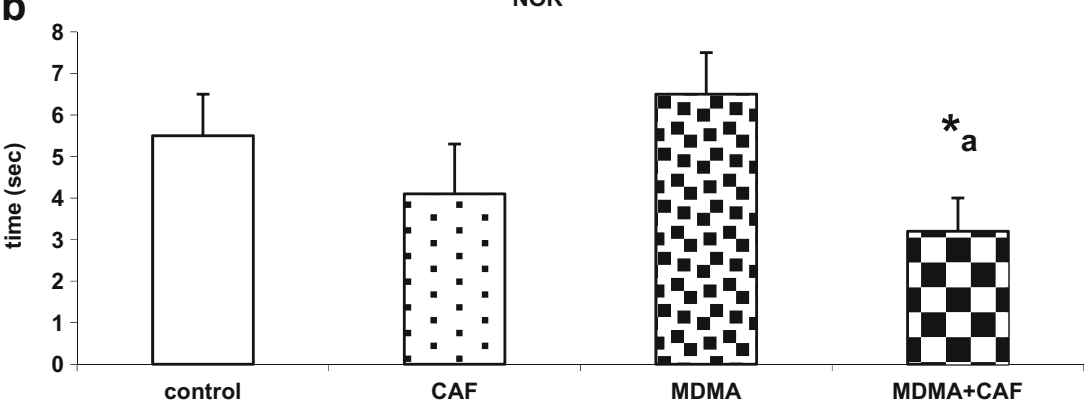


similar extent (e.g., 400-450\% of the basal value), but the effect of the last dose was weaker, and DA level reached the basal value at the end of the experiment. The pattern of 5-HT release was different showing more stable increase throughout the whole collection time. The total effect of MDMA on DA and 5-HT release presented as AUC was comparable. Thus, our in vivo data do not reflect the potency order of DAT and SERT inhibitions by MDMA in rat synaptosomes, where MDMA inhibited SERT stronger than DAT (Rothman et al. 2001). Moreover, MDMA applied in a single higher dose (i.e., $20 \mathrm{mg} / \mathrm{kg}$ ) was more potent in increasing DA than 5-HT release.

When MDMA was applied chronically (2 days of binge administration per week; this cycle was repeated three times), a weaker response of DA neurons to the challenging dose of MDMA but a stronger response of 5-HT ones was observed. Interestingly, the basal extracellular level of DA in mice receiving MDMA chronically was nearly twofold higher than in control animals, while extracellular 5-HT level was potently decreased. The total effect after chronic MDMA treatment (shown in Table 1) on DA release was reduced by $15 \%$ in comparison with control animals, while 5-HT release was potently increased to ca. $540 \%$ of control values. It may be speculated that persistent outflow of DA due to loss of DA uptake capacity may be a cause of increased basal extracellular DA level. Considerable evidence from the literature indicates that internalization of DAT occurs in response to amphetamine treatment (Saunders et al. 2000). Thus, decreased surface density of functional DAT may possibly be responsible for increased extracellular DA basal level and weaker effect of MDMA challenging dose on DA release through DAT. In fact, we observed a decrease in DAT density in the striatum and frontal cortex following chronic exposure to MDMA, which is in line with studies of Saunders et al. (2000). In contrast to the effects of MDMA on DA release, the basal extracellular 5-HT level was strongly suppressed in animals treated chronically with MDMA, but response to the challenging MDMA dose was very potent. This is probably due to compensatory upregulation of 5-HT release machinery resulting from low synaptic 5-HT levels. It is not clear whether a low basal extracellular 5HT level in animals treated chronically with MDMA results from dysfunctional SERT. In the study with MDMA selfadministration (Schenk et al. 2007) or its repeated application (Xie et al. 2006), a decrease in SERT was noted. Our data also show MDMA-induced decrease in SERT density in the striatum and frontal cortex of mice after its chronic administration. Since the loss of surface expression of SERT correlates with lowered 5-HT basal level, it may be speculated that 5-HT neuron terminals may be damaged by MDMA.

The different effect exerted by MDMA on 5-HT and DA has been revealed in a number of studies. For instance, Koch and Galloway (1997), Reveron et al. (2010), and Shankaran et al. (1999) found that depending on the dose, MDMA was several times more potent in influencing synaptic 5-HT than DA. The effect of MDMA on DA and 5-HT systems may be due to modulation of different receptors. Activation of 5-HT1A and 5-HT2A/2C receptors localized on DA cells and neuronal terminals or on GABA or glutamate neurons by 5-HT or directly by MDMA (Di Mateo et al. 2008) exerted rather inhibitory control on DA. However, some studies report that the activation of 5 HT1A (Ichikawa et al. 2001; Rollema et al. 2000), 5HT1B (Yan and Yan 2001; O’Dell and Parsons 2004), or 5-HT2A receptors in the frontal cortex (Pehek et al. 2006) increased DA release, whereas activation of 5-HT2C receptors was inhibitory to DA (Bankson and Yamamoto 2004). Thus, it may be suggested that long-term exposure to MDMA leads to neuroadaptative changes in sensitivity of serotonin receptors, which may result in differential response of DA and 5-HT neurons, as it is observed in our study. On the other hand, MDMA acting by itself or via SERT-released 5-HT may affect other neurotransmitter systems. Some data suggest a role of postsynaptic 5-HT2A receptors located on glutamatergic neurons in the neurochemical effects mediated by MDMA. Stimulation of 5HT2A receptors located on glutamatergic cells in the frontal cortex may elicit an increase in glutamate level leading indirectly to a rise in DA and 5-HT release (Alex and Pehek 2007). MDMA may also suppress nigral GABA release following $5-\mathrm{HT} 2 \mathrm{~A} / 2 \mathrm{C}$ receptor activation thus causing disinhibition of the striatal DA neurons (Gudelsky and Yamamoto 2008). One can speculate that the observed changes in 5-HT2A/C receptors may represent neuroadaptative responses secondary to changes in SERT expression induced by MDMA. However, it remains unclear how glutamate and GABA release may be involved in upregulation of serotonergic neurons and cause very potent response to the challenging dose of MDMA, as we observed in the present study.

\section{MDMA and Caffeine Co-administration Effect on DA and 5-HT Release}

Caffeine given repeatedly increased the basal extracellular level of DA and increased MDMA effect on DA release. However, in contrast to animals pretreated with saline in which caffeine potentiated MDMA-induced increase in 5HT release, caffeine inhibited the MDMA effect on 5-HT release in animals receiving both psychostimulants repeatedly. It is accepted that the mechanism underlying caffeine influence on neurotransmitter release is related to the blockade of adenosine $\mathrm{A} 1$ and $\mathrm{A} 2 \mathrm{~A}$ receptors. Caffeine may increase DA and glutamate release in the striatum via blockade of inhibitory A1 receptors as was evidenced by a number of studies (Borycz et al. 2007; Ciruela et al. 2006; Górska and Gołembiowska 2015; Okada et al. 1996). Similarly, adenosine A1 receptor blockade was 
shown to increase striatal and hippocampal 5-HT release (Górska and Gołembiowska 2015; Okada et al. 1999). There is also considerable evidence that $\mathrm{A} 2 \mathrm{~A}$ receptors highly expressed in striatopallidal GABAergic neurons (Ferré et al. 1993) and on striatal glutamatergic terminals (Ciruela et al. 2006) are involved in the enhancement of extracellular DA and 5-HT levels by caffeine. The lack of A2A receptors on the striatal monoaminergic neuronal terminals suggests that their role in the control of DA and 5HT release may be secondary and related to the changes in the activity of striatal output pathways elicited by postsynaptic A2A receptors. In support of this concept, there are studies showing that the administration of A2A adenosine receptor antagonists increased DA release and 5-HT release in the striatum of rats and mice (Gołembiowska et al. 2009, Górska and Gołembiowska 2015; Okada et al. 1996).

Chronic co-administration of caffeine and MDMA produced a stronger effect on DA release as compared to MDMA alone in response to the challenging doses of both psychostimulants. These data indicate synergistic interaction between caffeine and MDMA. It may be postulated that caffeine by blocking $\mathrm{A} 1$ and $\mathrm{A} 2 \mathrm{~A}$ receptors and MDMA via DAT could increase DA release in chronically pretreated animals. Our earlier study with a single-dose drug treatment indicates that caffeine-potentiated MDMA evoked DA release by blockade of $\mathrm{A} 1$ and $\mathrm{A} 2 \mathrm{~A}$ receptors (Górska and Gołembiowska 2015). However, other authors reported that the exacerbation of MDMA effect by caffeine in striatal slices was mediated via A1 receptors blockade (Vanattou-Saïfoudine et al. 2011). The difference in results reported by the above-cited studies may be related by way of drug application (systemic vs. local) and animal species (mice vs. rats).

The diminished response of 5-HT neurons after coadministration of caffeine and MDMA as compared to MDMA alone is difficult to explain. It may be speculated that persistent blockade of adenosine receptors by caffeine can be responsible for this effect. It was demonstrated that adenosine $\mathrm{A} 1, \mathrm{~A} 2$, and $\mathrm{A} 3$ receptors could modulate hippocampal 5-HT release (Okada et al. 1999). In the study of Okada et al. (1999), the stimulatory effects of A2 and inhibitory effects of A3 receptors on 5-HT release were abolished by A1 receptor activation. However, under A1 receptor blockade by caffeine, the inhibitory effects of A3 receptor were unmasked in addition to the effect of A2 receptor blockade by caffeine (Okada et al. 1999, 2001). Furthermore, it was also demonstrated that 5-HT reuptake activity might be modulated by A3 receptor (Okada et al. 2001). Thus, the described mechanism of adenosine receptor involvement in the control of 5-HT release and their blockade by caffeine may be responsible for the diminished 5-HT release in response to MDMA and caffeine co-administration.

\section{Neurotoxic Effects of MDMA and Caffeine}

The neurotoxic effect of MDMA in mice seems to be related to dopaminergic and serotonergic systems. Our data showed a significant decrease in markers of neuronal terminals, DAT, and SERT in the mouse striatum and frontal cortex after chronic administration of MDMA. There was also depletion of tissue concentration of DOPAC and 5-HIAA, but not DA and 5-HT, in the striatum and the frontal cortex of mice. Neurotoxic effect seems to result from formation of ROS because we observed oxidative damage of neuronal DNA in the cortex 2 months after acute and chronic doses of MDMA. In addition, the formation of free radicals after MDMA administration in the mouse striatum was evidenced in our earlier study (Górska et al. 2014). The role of ROS in MDMA neurotoxicity was also demonstrated in many other works. Free radical formation by MDMA was found in the mouse striatum by Colado et al. (2001). The involvement of free radicals in MDMA-induced dopaminergic neurotoxicity in mice was also shown by Peraile et al. (2013). Those authors demonstrated that oxidative stress was related with lipid peroxidation and with an increase in superoxide dismutase and decrease in catalase activity. Hydroxyl radical formation together with products of tryptamine oxidation was proposed as the mechanism of MDMA-induced depletion of brain 5-HT by Shankaran et al. (1999). Moreover, it was suggested that 5-HT depletion was dependent on 5-HT transporter activity. It is speculated that DA released by MDMA may enter the 5-HT terminal through SERT and may be oxidized by MAO-B, which is present in 5-HT terminals, leading to the generation of free radicals in 5-HT neurons (Falk et al. 2002; Shankaran et al. 1999). Barbosa et al. (2012) indicated that MDMA metabolites, in particular $\alpha$-methyl-dopamine, together with high levels of monoamine neurotransmitters might be the major contributors to MDMA neurotoxic effects.

Oxidative damage produced by MDMA may be associated with neuronal cell bodies. As shown in our work, MDMA caused single- and double-strand breaks in cortical nuclear DNA. Reactive oxygen species, in particular hydrogen radical, formed even after a single dose of MDMA, are able to interact with DNA bases. In our study, oxidative stress triggered DNA alterations which persisted for 2 months after single or repeated doses of MDMA. Most of the literature has described the striatum as the main target of MDMA neurotoxicity. Here, we provide evidence that other regions are also targets of MDMA neurotoxicity. DNA damage may be a molecular basis for MDMA-induced neuroplasticity with subsequent behavioral and cognitive deficits. In our study, caffeine co-administered with MDMA promoted damage of nuclear DNA 2 months after termination of the treatment; thus, it enhanced oxidative stress induced by MDMA. Caffeine also enhanced the decrease in cortical DOPAC and 5-HIAA in the striatum and frontal cortex. At the same time, it slightly but 
significantly reversed the decrease in striatal DOPAC content and increased DA striatal tissue level. It can be concluded that caffeine increased MDMA-induced deficit in striatal 5-HT neurons and DA deficit in the frontal cortex. However, it was neuroprotective for DA fibers in the striatum. These data partially correspond to our results with measurement of SERT and DAT fiber densities. In these experiments, caffeine reversed the decrease in striatal DAT-positive fibers in animals treated with MDMA. However, it had no effect on DAT- and SERT-positive fibers in the frontal cortex and striatum, respectively. On the other hand, it potentiated the decrease in cortical SERT fiber density. It has to be pointed out that reversal of MDMA-induced decrease in DAT fiber density by caffeine corresponds to the caffeine-induced enhancement of the effect of MDMA on DA release in the striatum. Thus, caffeine seems to be neuroprotective for striatal dopaminergic fibers, but it seems to increase neurotoxic damage of cortical 5-HT terminals. Moreover, besides damage of cortical 5-HT terminals, caffeine increased MDMA-induced oxidative damage of cortical DNA which suggests degeneration of neuronal cells in this brain region. The neurotoxic effect exerted on cortical neuronal cell bodies may lead to neuroadaptive change of cortical pathways projecting to nigral or raphe nuclei. Thus, overall caffeine effect seems to be partly neuroprotective and partly neurotoxic. This dual action is dependent on doses, the brain region examined, and the schedule of administration as reported by numerous literature. Caffeine has been shown to have neuroprotective properties in the animal model of Parkinson's disease (PD) (Kalda et al. 2006) and decreased the risk of development of PD as was demonstrated by several epidemiological studies (Ascherio et al. 2001; Ross et al. 2000). When caffeine was given chronically, it increased activity of antioxidant enzymes superoxide dismutase (SOD) and catalase (CAT) in several regions of the rat brain (Noschang et al. 2009a). Aoyama et al. (2011) evidenced that caffeine induced neuronal glutathione (GSH) synthesis by promoting cysteine uptake in mouse hippocampal pyramidal neurons. Chronic caffeine ingestion reduced the lipid peroxidation and increased GSH level and SOD activity in the rat brain (Abreu et al. 2011). On the other hand, caffeine exhibited prooxidant properties in vitro (Azam et al. 2003) and inhibited DNA repair mechanisms (Selby and Sancar 1990). The neurotoxic potential of caffeine given acutely was evidenced in the mouse brain by enhanced astroglia and microglia reactivities by MDMA (Khairnar et al. 2010). In contrast, chronic low doses of caffeine exerted anti-inflammatory effects and prevented MDMA-induced neuroinflammatory reaction (Ruiz-Medina et al. 2013). Study of Frau et al. (2016) showed that caffeine potentiated MDMA-induced DA neuron degeneration and neuroinflammation in adolescent mice. Vanattou-Saïfoudine et al. (2012) proposed that caffeine exacerbated adverse reactions induced by various psychostimulants, such as hyperthermia, tachycardia, and increased mortality as the result of increased DA release. Thus, caffeine shows differential effects, neuroprotective or neurotoxic, when co-administered with MDMA indicating that the mechanism of action of psychoactive drug combination needs further clarification.

\section{MDMA and Caffeine Effects on PDYN and PENK Gene Expressions and on Behavior}

In our study, chronic MDMA increased PDYN gene expression in medium spiny GABA neurons expressing D1 receptor, while it did not affect PENK expression in GABA neurons projecting to the globus pallidus expressing D2 receptor. This is in line with findings of Benedetto di et al. (2006), who reported an increase in PDYN expression in the rat striatum after chronic administration of MDMA. These data confirm also the role of D1 receptor in MDMA effects, in particular in the development of neurotoxicity after long-term administration (Granado et al. 2014). The overstimulation of a direct GABAergic pathway with normal functioning of an indirect GABAergic pathway may be responsible for deficit in locomotor activity of mice observed in our study. The lack of caffeine influence on MDMA-induced PDYN expression seems to correlate with its lack on MDMAinduced locomotor activity of mice in the open-field test. As mentioned in the "Introduction" section, caffeine increases the activity of both types of neurons (Johansson et al. 1994). Thus, balanced effect on both GABAergic pathways by caffeine may underlie the lack of influence on the PENK expression. On the other hand, caffeine coadministered chronically with MDMA decreased the time of exploration of unknown object in the novel object recognition test. It is likely that a combination of both psychostimulants induced deficit in cognitive functions of mice, as also demonstrated by Costa et al. (2014). Structural synaptic plasticity of the medial prefrontal cortex was correlated with changes in response to novelty in rats developmentally treated with cocaine (Caffino et al. 2017). It may be suggested that damage of serotonergic terminals in cortical regions or possible oxidative damage of glutamatergic pathways projecting to the VTA or raphe cell bodies may be responsible for the effect of psychostimulants on cognitive functions. The role of glutamatergic pathway damage by oxidative stress in the hippocampus and cognitive impairment was also shown in mice by Frenzilli et al. (2007). Anxiety-like behavior in rats was related to oxidative damage of DNA in the hippocampus by chronic caffeine (Noschang et al. 2009b). The alterations in the brain antioxidant system were suggested to affect the cognitive functions of rats after chronic caffeine ingestion (Abreu et al. 2011). 


\section{Conclusions}

In conclusion, our data provide evidence that long-term caffeine administration has a powerful influence on dopaminergic and serotonergic neuron functions disturbed by MDMA in the mouse brain and on neurotoxic effects evoked by MDMA. Caffeine potentiates MDMA effect on dopaminergic system and inhibits its effect on serotonergic neurons. Exacerbation of MDMA-evoked oxidative stress may cause damage of serotonergic terminals.

Acknowledgements Anna Maria Górska was a holder of IBRO in Europe Short Stay Grants Programme Award.

Funding Information The study was supported by project 2013/11/N/ NZ7/00740 from the National Science Centre and statutory funds from the Institute of Pharmacology, Polish Academy of Sciences (Kraków. Poland).

Compliance with Ethical Standards The experiments were conducted in accordance with the European Union guidelines regarding the care and use of laboratory animals (Council Directive 86/609/EEC of November 24, 1986) and were approved by the II Local Bioethics Commission (Kraków, Poland).

Open Access This article is distributed under the terms of the Creative Commons Attribution 4.0 International License (http:// creativecommons.org/licenses/by/4.0/), which permits unrestricted use, distribution, and reproduction in any medium, provided you give appropriate credit to the original author(s) and the source, provide a link to the Creative Commons license, and indicate if changes were made.

\section{References}

Abreu RV, Silva-Oliveira EM, Moraes MFD, Pereira GS, Moraes-Santos $T$ (2011) Chronic coffee and caffeine ingestion effects on the cognitive function and antioxidant system of rat brains. Pharmacol Biochem Behav 99:659-664

Alex KD, Pehek EA (2007) Pharmacologic mechanisms of serotonergic regulation of dopamine neurotransmission. Pharmacol Ther 113: 296-320

Aoyama K, Matsumbra N, Watabe M, Wang F, Kikuchi-Utsumi K, Nakaki T (2011) Caffeine and uric acid mediate glutathione synthesis for neuroprotection. Neuroscience 181:206-215

Ascherio A, Zhang SM, Hernan MA, Kawachi I, Colditz GA, Speizer FE, Willet WC (2001) Prospective study of caffeine consumption and risk of Parkinson's disease in men and women. Ann Neurol 50:56-63

Azam S, Hadi N, Khan NU, Hadi SM (2003) Antioxidant and prooxidant properties of caffeine, theobromine and xanthine. Med Sci Monit 9: BR325-BR330

Bankson MG, Yamamoto BK (2004) Serotonin-GABA interactions modulate MDMA-induced mesolimbic dopamine release. J Neurochem 91:852-859

Barbosa DJ, Capela JP, Oliveira JMA, Silva R, Ferreira LM, Siopa F, Branco PS, Fernades E, Duarte JA, Bastos ML, Carvalho F (2012) Pro-oxidant effects of ecstasy and its metabolites in mouse brain synaptosomes. Br J Pharmacol 165:1017-1033

Baumann MH, Clark RD, Budzynski AG, Partilla JS, Blough BE, Rothman RB (2005) N-Substituted piperazines abused by humans mimic the molecular mechanism of 3,4-methylenedioxymethamphetamine (MDMA, or "ecstasy"). Neuropsychopharmacology 30:550-560

Benedetto di M, D'Addario C, Candelettio S, Romualdi P (2006) Chronic and acute effects of 3,4-methylenedioxy-N-methylamphetamine ('ecstasy') administration on the dynorphinergic system in the rat brain. Neuroscience 137:187-196

Borycz J, Pereira MF, Melani A, Rodrigues RJ, Köfalvi A, Panlilio L, Pedata F, Goldberg SR, Cunha RA, Ferré S (2007) Differential glutamate-dependent and glutamate-independent adenosine A1 receptor-mediated modulation of dopamine release in different striatal compartments. J Neurochem 101:355-363

Brodkin J, Malyala A, Nash JF (1993) Effect of acute monoamine depletion on 3,4-methylenedioxymethamphetamine-induced neurotoxicity. Pharmacol Biochem Behav 45:647-653

Cadet JL, Thiriet N, Jayanthi S (2001) Involvement of free radicals in MDMA-induced neurotoxicity in mice. Ann Med Interne (Paris) 152(Suppl. 3):1557-1550

Caffino L, Giannotti G, Mottarlini F, Racagni G, Fumagalli F (2017) Developmental exposure to cocaine dynamically dysregulates cortical Arc/Arg3.1 modulation in response to a challenge. Neurotox Res 31:289-297

Camarasa J, Bubill D, Escubedo E (2006) Association of caffeine to MDMA does not increase antinociception but potentiates adverse effects of this recreational drug. Brain Res 1111:72-82

Capela JP, Fernades E, Remião F, Bastos ML, Meisel A, Carvalho F (2007) Ecstasy induces apoptosis via 5-HT2A-receptor stimulation in cortical neurons. NeuroToxicology 28:868-875

Ciruela F, Casadó V, Rodrigues RJ, Luján R, Burgueño J, Canals $\mathrm{M}$ et al (2006) Presynaptic control of striatal glutamatergic neurotransmission by adenosine $A_{1}-A_{2 A}$ receptors heteromers. J Neurosci 26:2080-2087

Colado MI, Camarero J, Mechan AO, Sanchez V, Esteban B, Elliott JM, Green AR (2001) A study of the mechanism involved in the neurotoxic action of 3,4-methylenedioxymethamphetamine (MDMA, 'ecstasy') on dopamine neurons in mouse brain. Br J Pharmacol 134: $1711-1723$

Costa G, Frau L, Wardas J, Pinna A, Plumitallo A, Morelli M (2013) MPTP-induced dopamine neuron degeneration and glia activation is potentiated in MDMA-pretreated mice. Mov Disord 28:1957-1965

Costa G, Simola N, Morelli M (2014) MDMA administration during adolescence exacerbates MPTP-induced cognitive impairment and neuroinflammation in the hippocampus and prefrontal cortex. Psychopharmacology 231:4007-4018

Curan EJ, Watson SJ Jr (1995) Dopamine receptor mRNA expression patterns by opioid peptide cells in the nucleus accumbens of the rat: a double in situ hybridization study. J Comp Neurol 361:57-76

De la Torre R, Farre M (2004) Neurotoxicity of MDMA (ecstasy): the limitation of scalling from animals to humans. Trends Pharmacol Sci 25:505-508

Di Mateo V, Di Giovanni G, Pierucci M, Esposito E (2008) Serotonin control of central dopaminergic function: focus in in vivo microdialysis studies. Prog Brain Res 172:7-44

Falk EM, Cook VJ, Nichols DE, Sprague JE (2002) An antisense oligonucleotide targeted at MAO-B attenuates rat striatal serotonergic neurotoxicity induced by MDMA. Pharmacol Biochem Behav 72:617-622

Ferré S, O'Connor WT, Fuxe K, Ungerstedt U (1993) The striatopallidal neuron : a main locus for adenosine-dopamine interactions in the brain. J Neurosci 13:5402-5406

Frau L, Simola N, Plumitallo A, Morelli M (2013) Microglial and astroglial activation by 3,4-methylenedioxymethamphetamine (MDMA) in mice depends on $\mathrm{S}(+)$ enantiomer and is associated with an increase in body temperature and motility. J Neurochem 124:69-78

Frau L, Costa J, Porceddu PF, Khairnar A, Castelli MP, Ennas MG, Madeddu C, Wardas J, Morelli M (2016) Influence of caffeine on 3,4-methylenedioxymethamphetamine-induced dopaminergic neuron degeneration and neuroinflammation is age-dependent. $\mathrm{J}$ Neurochem 136:148-162 
Frenzilli G, Ferrucci M, Giorgi FS, Blandini F, Nigro M, Ruggieri S, Murri L, Paparelli A, Fornai FF (2007) DNA fragmentation and oxidative stress in the hippocampal formation: a bridge between 3 , 4-methylenedioxymethamphetamine (ecstasy) intake and longlasting behavioral altertations. Behav Pharmacol 18:471-481

Gerfen CR, Engber TM, Mahan LC, Susel Z, Chase TN, Monsma FJ Jr, Sibley DR (1990) D1 and D2 dopamine receptor-regulated gene expression of striatonigral and striatopallidal neurons. Science 250: $1429-1432$

Gołembiowska K, Dziubina A, Kowalska M, Kamińska K (2009) Effect of adenosine A2A receptor antagonists on L-DOPA-induced hydroxyl radical formation in rat striatum. Neurotox Res 15:155-166

Górska A, Gołembiowska K (2015) The role of adenosine A1 and $\mathrm{A} 2 \mathrm{~A}$ receptors in the caffeine effect on MDMA-induced DA and 5-HT release in the mouse striatum. Neurotox Res 27: $229-245$

Górska AM, Noworyta-Sokołowska K, Gołembiowska K (2014) The effect of caffeine on MDMA-induced hydroxyl radical production in the mouse striatum. Pharmacol Rep 66:718-721

Granado N, Ares-Santos S, Moratalla R (2014) D1 but not D4 dopamine receptors are critical for MDMA-induced neurotoxicity in mice. Neurotox Res 25:100-109

Green AR, Mechan AO, Elliott JM, O'Shea E, Colado MI (2003) The pharmacology and clinical pharmacology of 3,4methylenedioxymethamphetamine (MDMA, "ecstasy"). Pharmacol Rev 55:463-508

Green AR, O'Shea E, Colado MI (2004) A review of the mechanisms involved in the acute MDMA ('ecstasy')-induced hyperthermic response. Eur J Pharmacol 500:3-13

Gudelsky GA, Yamamoto BK (2008) Actions of 3,4methylenedioxymethamphetamine (MDMA) on cerebral dopaminergic, serotonergic and cholinergic neurons. Pharmacol Biochem Behav 90:198-207

Ichikawa J, Ishii H, Bonaccorso S, Fowler WL, O'Laughlin IA, Meltzer HY (2001) 5-HT(2A) and $\mathrm{D}(2)$ receptor blockade increases cortical DA release via $50 \mathrm{HT}(1 \mathrm{~A})$ receptor activation: a possible mechanism of atypical antipsychotic-induced cortical dopamine release. J Neurochem 76:1521-1531

Johansson B, Lindström K, Fredholm BB (1994) Differences in the regional and cellular localization of $c-f o s$ messenger RNA induced by amphetamine, cocaine and caffeine in the rat. Neuroscience 59:837-849

Kalda A, Yu L, Oztas E, Chen JF (2006) Novel neuroprotection by caffeine and adenosine A2A receptro antagonists in animal models of Parkinson's disease. J Neurol Sci 248:9-15

Khairnar A, Plumitallo A, Frau L, Schintu N, Morelli M (2010) Caffeine enhances astroglia and microglia reactivity induced by $3,4-$ methylenedioxymethamphetamine ('ecstasy') in mouse brain. Neurotox Res 17:435-439

Khairnar A, Frau L, Plumitallo A, Morelli M, Simola N (2014) Antagonism of adenosine $\mathrm{A} 1$ and $2 \mathrm{~A}$ receptors amplifies the effects of MDMA on glial activation in the mouse brain: relevance to caffeine-MDMA interactions. J Caffeine Res 4:41-47

Koch S, Galloway MP (1997) MDMA induced dopamine release in vivo: role of endogenous serotonin. J Neural Transm 104:135-146

Leonardi ET, Azmitia EC (1994) MDMA (ecstasy) inhibition of MAO type A and type B: comparisons with fenfluramine and fluoxetine (Prozac). Neuropsychopharmacology 10:231-238

Lopez-Rodriguez AB, Llorente-Berzal A, Garcia-Segura LM, Viveros MP (2014) Sex-dependent long-term effects of adolescent exposure to THC and/or MDMA on neuroinflammation and serotonergic and cannabinoid systems in rats. Br J Pharmacol 171:1435-1447

McCann UD, Szabo Z, Seckin E, Rosenblatt P, Mathews WB, Ravert HT et al (2005) Quantitative PET studies of the serotonin transporter in MDMA users and controls using [11C]McN5652 and [11C]DASB. Neuropsychopharmacology 30:1741-1750
McNamara R, Kerans A, O’Neill B, Harkin A (2006) Caffeine promotes hyperthermia and serotonergic loss following co-administrationof the substituted amphetamines, MDMA ("ecstasy") and MDA ("love"). Neuropharmacology 50:69-80

Noschang CG, Krolow R, Pettenuzzo LF, Ávila MC, Fachin A, Arcego D, Toigo EP, Crema LM, Diehl LA, Vendite D, Dalmaz C (2009a) Interactions between chronic stress and chronic consumption of caffeine on the enzymatic antioxidant system. Neurochem Res 34: $1568-1574$

Noschang CG, Pettenuzzo LF, von Pozzer Toigo E, Andreazza AC, Krolow R, Fachin A, Ávila MC, Arcego D, Crema LM, Diehl LA, Gonçalvez CA (2009b) Sex-specific differences on caffeine consumption and chronc stress-induced anxiety-like behavior and DNA breaks in the hippocampus. Pharmacol Biochem Behav 94:63-69

O'Dell LE, Parsons LH (2004) Serotonin 1B receptors in the ventral tegmental area modulate cocaine-induced increases in nucleus accumbens dopamine levels. J Pharmacol Exp Ther 311:711-719

Okada M, Mizuno K, Kaneko S (1996) Adenosine A1 and A2 receptors modulate extracellular dopamine levels in rat striatum. Neurosci Lett 212:53-56

Okada M, Kiryu K, Kawata Y, Mizuno K, Wada K, Tasaki H, Kaneko S (1997) Determination of the effects of caffeine and carbamazepine on striatal dopamine release by in vivo microdialysis. Eur J Pharmacol 321:181-188

Okada M, Kawata Y, Murakami T, Wada K, Misuno K, Kondo T et al (1999) Differentia effects of adenosine receptor subtypes on release and reuptake of hippocampal serotonin. Eur J Neurosci 11:1-9

Okada M, Nutt DJ, Murakami T, Zhu G, Kamata A, Kawata Y, Kaneko S (2001) Adenosine receptor subtypes modulate two major functional pathways for hippocampal serotonin release. J Neurosci 21:628-640

Paxinos G, Franklin KBJ (2008) The mouse brain in stereotaxic coordinates, 3rd edn. Academic Press, San Diego

Peacock A, Bruno R, Ferris J, Winstock A (2017) Energy drink use frequency among an international sample of people who use drugs: associations with other substance use and well-being. Drug Alcohol Depend 174:70-79

Pehek EA, Nocjar C, Roth BL, Byrd TA, Mabrouk OS (2006) Evidence for the preferential involvement of 5-HT2A serotonin receptors in stress- and drug-induced dopamine release in the rat medial prefrontal cortex. Neuropsychopharmacology 31:265-277

Peraile I, Granado N, Torres E, Gutiérrez-López MD, Moratalla R, Colado MI, O'Shea E (2013) Cocaine potentiates MDMA-induced oxidative stress but not dopaminergic neurotoxicity in mice: implications for the pathogenesis of free radical-induced neurodegenerative disorders. Psychopharmacology 230:125-135

Reveron ME, Maier EY, Duvauchelle CL (2010) Behavioral, thermal and neurochemical effects of acute and chronic 3,4methylenedioxymethamphetamine (ecstasy) self-administration. Behav Brain Res 2007:500-507

Ricuarte GA, Forno LS, Wilson MA, DeLanney LE, Irwin I, Molliver M E, L a n g s t o n J W ( 1988 ) ( 1 ( ) 3, 4 Methylenedioxymethamphetamineselectively damages central serotonergic neurons in nonhuman primates. JAMA 260:51-55

Rollema H, Lu Y, Schmidt AW, Sprouse JS, Zorn SH (2000) 5$\mathrm{HT}(1 \mathrm{~A})$ receptor activation contributes to ziprasidone-induced dopamine release in the rat prefrontal cortex. Biol Psychol 48:229-237

Ross GW, Abbott RD, Petrovitch H, Morens DM, Grandinetti A, Tung KH, Taner CM, Masaki KH, Blanchette PL, Curb JD, Propper JS, White LR (2000) Association of coffee and caffeine intake with the risk of Parkinson disease. JAMA 283:2674-2679

Rothman RB, Bauman MH, Dersch CM, Romero DV, Rice KC, Carroll FI, Partilla JS (2001) Amphetamine-type central nervous system 
stimulants release norepinephrine more potently than they release dopamine and serotonin. Synapse 39:32-41

Rudnick G, Wall SC (1992) The molecular mechanism of "ecstasy" [3,4methylenedioxy-methamphetamine (MDMA)]: serotonin transporters are targets for MDMA-induced serotonin release. Proc Natl Acad Sci U S A 89:1817-1821

Ruiz-Medina J, Pinto-Xavier A, Rodríguez-Arias M, Miñarro J, Valverde O (2013) Influence of chronic caffeine on MDMA-induced behavioral and neuroinflammatory response in mice. Psychopharmacology 226:433-444

Saunders C, Ferrer JV, Shi L, Chen J, Merrill G, Lamb ME, LeebLundberg LMF, Carvelli L, Javitch JA, Galli A (2000) Amphetamine-induced loss of human dopamine transporter activity: an internalization-dependent and cocaine-sensitive mechanism. Proc Natl Acad Sci U S A 97:6850-6855

Schenk S, Hely L, Lake B, Daniela E, Gittings D, Mash DC (2007) MDMA self-administration in rats: acquisition, progressive ratio responding and serotonin transporter binding. Eur J Neurosci 26: 3229-3236

Selby CP, Sancar A (1990) Molecular mechanisms of DNA repair inhibition by caffeine. Proc Natl Acad Sci 87:3522-3525

Shankaran M, Yamamoto BK, Gudelsky GA (1999) Involvement of the serotonin transporter in the formation of hydroxyl radicals induced by 3,4-methylenedioxymethamphetamine. Eur J Pharmacol 385: $103-110$

Sprague JE, Nichols DE (2005) Neurotoxicity of MDMA (ecstasy): beyond metabolism. Trends Pharmacol Sci 26:59-60

Sulzer D, Sonders MS, Poulsen NW, Galli A (2005) Mechanisms of neurotransmitter release by amphetamines: a review. Prog Neurobiol 75:406-433
Svenningsson P, Georgieva J, Kontny E, Heilig M, Fredholm BB (1997) Caffeine regulates the preprotachykinin $\mathrm{A}$ and neurotensin/ neuromedin $\mathrm{N}$ genes via a c-fos dependent mechanism in rat striatum. Eur J Neurosci 9:2135-2141

Vanattou-Saïfoudine N, McNamara R, Harkin A (2010a) Caffeine promotes dopamine D1 receptor-mediated body temperature, heart rate and behavioural responses to MDMA ('ecstasy'). Psychopharmacology 211:15-25

Vanattou-Saïfoudine N, McNamara R, Harkin A (2010b) Mechanisms mediating the ability of caffeine to influence MDMA ('ecstasy')-induced hyperthermia in rats. Brit. Aust J Pharm 160:860-877

Vanattou-Saïfoudine N, Gossen A, Harkin A (2011) A role for adenosine A1 receptors blockade in the ability of caffeine to promote MDMA "ecstasy"-induced striatal dopamine release. Eur J Pharmacol 650: $220-228$

Vanattou-Saïfoudine N, McNamara R, Harkin A (2012) Caffeine provokes adverse interactions with 3,4-methylenedioxymethamphetamine (MDMA, 'ecstasy') and related psychostimulants: mechanisms and mediators. Brit Aust J Pharm 167:946-959

Vincent SR, Hökfelt T, Christensson I, Terenius L (1982) Dynorphinimmunoreactive neurons in the central nervous system of the rat. Neurosci Lett 33:185-190

Xie T, Tong L, McLane MW, Hatzidimitriou G, Yuan J, McCann U, Ricuarte G (2006) Loss of serotonin transporter protein after MDMA and other ring-substituted amphetamines. Neuropsychopharmacology 31:26392651

Yan QS, Yan SE (2001) Activation of 5-HT(1B/1D) receptors in the mesolimbic dopamine system increases dopamine release from the nucleus accumbens: a microdialysis study. Eur J Pharmacol 418:55-64 